\title{
Facciosismo, Rachas Intrapartidários e Capacidade Decisória na Democracia Brasileira de $1946^{*}$
}

Jaqueline Porto Zulini

Universidade de São Paulo (USP), São Paulo, SP, Brasil. E-mail: jaquepz@gmail.com

\section{INTRODUÇÃO}

\begin{abstract}
A ordem democrática instituída no Brasil após a queda do Estado Novo entrou para os anais da historiografia política como o reino do facciosismo. Frequentemente, as monografias disponíveis sobre os maiores partidos da República de 1946 a 1964 reconhecem a dificuldade enfrentada pelas legendas na tentativa de harmonizar as várias forças antagônicas que formavam os seus quadros (Benevides, 1981a; D’Araújo, 1992; Hippólito, 1985; Sampaio, 1982). Inimigos políticos e desafetos jurados se sujeitavam a dividir uma mesma filiação política por causa do caráter compulsório que o registro partidário assumiu no novo regime, tornando-se precondição para candidaturas a cargos eletivos (Benevides, 1981a) ${ }^{1}$. Como consequência, a bibliografia aponta que o convívio entre rivais frequentemente redundava em diferenças na arena parlamentar, com o levante de múltiplos subgrupos no interior das siglas, fragilizadas pelas cisões constantes. Tamanhas eram as correntes observadas no seio da União Democrática Nacional (UDN) e do Partido Socialista Progressista (PSP) que os especialistas tenderam,
\end{abstract}

\footnotetext{
* Este artigo sintetiza as conclusões apresentadas na minha dissertação de Mestrado, desenvolvida com o apoio da Fundação de Amparo à Pesquisa do Estado de São Paulo (Fapesp). Agradeço aos comentários de Argelina Cheibub Figueiredo, Fernando Limongi, Marta Arretche e Paolo Ricci às versões preliminares deste texto, bem como aos apontamentos dos pareceristas anônimos de DADOS - Revista de Ciências Sociais. Quaisquer imprecisões que restem são de minha inteira responsabilidade.
}

DADOS - Revista de Ciências Sociais, Rio de Janeiro, vol. 58, no 4, 2015, pp. 1017 a 1056. 
por muito tempo, a pensá-los como movimentos políticos - e não propriamente como partidos (Benevides, 1981a; Sampaio, 1982). A experiência dos petebistas autorizava leitura semelhante, havendo relatos de enfrentamento entre as muitas alas que se digladiavam para tomar a direção do Partido Trabalhista Brasileiro (PTB) (D'Araújo, 1992). Até mesmo a maior agremiação do período teria convivido com contendas internas consideráveis, sucumbindo quando já não se mostrava mais capaz de equalizá-las - e levando consigo a estabilidade do regime. $\mathrm{Na}$ versão de Hippólito (1985), o Partido Social Democrático (PSD) fora o avalista do regime de 1946, que rui justamente devido ao crescente radicalismo dos reformistas frente aos ditames das Raposas, como eram conhecidos os pessedistas tradicionais. O embate entre as frentes terminaria por deslocar a legenda da sua posição original no eixo político, de centro, considerada pela autora elemento basilar para a manutenção do sistema então em voga (Hippólito, 1985:141).

Abordagens focadas na interpretação do sistema representativo como um todo endossaram este facciosismo histórico, inferindo causas e implicações. Deduziram da herança clientelística que abatia a estrutura partidária, recém-reativada como canal de representação de interesses e participação política, a debilidade organizacional das legendas: organizações incapazes de conter e administrar o levante de subdivisões internas (Leal, 1975; Petersen, 1962; Schwartzman, 1971; Souza, 1976; para citar alguns). Problemas de coesão seriam tão corriqueiros que os governos ficariam à mercê da formação de coalizões no Congresso para assegurar maioria, normalmente concebidas ad hoc (Carvalho, 1977; D’ Araújo, 1992; Lafer, 1970, 2002; Santos, 1973; Skidmore, 1975). O raciocínio foi mantido em estudos mais recentes, que indicaram a fragilidade das siglas e da própria capacidade governativa no pré-1964, considerando produto do embate trivial entre dissidências políticas intrapartidárias a prevalência de composições de ocasião, cultivadas segundo interesses imediatistas de parlamentares com franca tendência apartidária (Amorim Neto e Santos, 2001; Figueiredo e Limongi, 1998, 2007; Santos, W., 2003; Santos, 2002). Contudo, as poucas pesquisas que tangenciaram o facciosismo de 1946-1964 mediram a indisciplina partidária no âmbito legislativo se limitando em detalhar somente a conduta das legendas de oposição. Além disso, trataram as siglas como atores unitários, apesar de apontarem a vigência de um aparente padrão sedicioso, indicado pela habitual baixa coesão das bancadas nas votações nominais. E, o mais importante: as referidas investigações não definiram bem o facciosismo, associando-o a coalizões 
ad hoc quando a própria noção de facciosismo implica a visualização de grupos bem coordenados (Amorim Neto e Santos, 2001; Carvalho, 1977; Santos, F., 2003).

Este artigo procura entender o impacto dos rachas intrapartidários sobre a capacidade decisória da democracia de 1946. A primeira seção retoma os termos do debate que enfatiza o facciosismo como um dos principais empecilhos para o decision making no pré-1964 e, na sequência, revela o desempenho do governo nas votações nominais das matérias iniciadas pelo Poder Executivo e sua base parlamentar na Câmara dos Deputados. Para mensurar a repercussão que os propalados rachas ideológicos no interior das legendas teve em plenário, a segunda seção busca operacionalizar o facciosismo a ponto de diferenciar os votos destes "grupos internos aos partidos que agem coletivamente para alcançar objetivos comuns", seguindo o conceito de facção estabelecido em Verge e Gómez (2012:669, tradução livre). Os resultados obtidos a partir desta perspectiva, criticados em seção distinta, não apontam correntes intrapartidárias claramente definidas no seio da coalizão de apoio ao governo, muito menos a constante contribuição decisiva da oposição na aprovação das agendas presidenciais, à exceção de uma coalizão varguista. Na maior parte das vezes, a base parlamentar do Poder Executivo no Congresso conseguia administrar, sozinha, o alcance das metas que estimava, dependendo pouco de auxílios externos. Aparentemente, o apoio da coalizão era assegurado pelo uso estratégico da verificação de quorum, um procedimento regimental que explicitava a divisão de forças no plenário e facilitava a coordenação da base, tratado na última seção do texto. A discussão final sugere que os especialistas têm sobredimensionado o efeito do facciosismo sobre a capacidade decisória e os saldos políticos delineados no Legislativo Federal durante a democracia de 1946.

\section{“FACCIOSISMO" E CAPACIDADE DECISÓRIA NO PRÉ-1964}

Em geral, a literatura sobre 1946-1964 destaca o facciosismo entre os elementos que desafiavam a capacidade decisória do período. Segundo a interpretação corrente, os partidos políticos na democracia de 1946 eram estruturas débeis, de coesão questionável, incapazes de coordenar divergências internas (Benevides, 1979, 1981a, 1981b; Leal, 1975; Oliveira, 1973; Sampaio, 1982; Souza, 1976). Fisiologistas manteriam relações de poder pautadas em clientelismo no decorrer de todo o regime $^{2}$. O Diretório Nacional do PSD, por exemplo, toleraria peculia- 
ridades estaduais e locais a favor da solução dos vários conflitos internos vivenciados pela agremiação entre 1946 e 1964, evitando se indispor com os interesses regionais - a esfera que realmente coordenava a oferta de votos aos pessedistas (Oliveira, 1973). Na mesma diretriz, a linha de ação característica dos quadros da UDN repousava sobre laços tradicionais e conservadores (Benevides, 1979). Aliados formalmente ao Executivo por quase toda a chamada democracia "populista", os próprios trabalhistas tampouco se revelariam menos propensos à política de clientela, sobretudo a seção paulista, minada "pelo empreguismo e pelo tráfico de influências" (Cardoso, 1978:46). Retrato idêntico caberia ao PSP, sigla cujo controle da direção no nível do município significava, "para os chefes políticos locais, o monopólio do acesso aos favores governamentais - e estes abrangiam desde o atendimento a pedidos de nomeação de funcionários" à "alocação de benefícios para o município" (Sampaio, 1982:136) ${ }^{3}$.

Partiu justamente da admissão dessa conjuntura a ideia de que prevaleceriam, na época, coalizões de apoio ao governo concebidas ad hoc, conforme os interesses de ocasião dos parlamentares (Carvalho, 1977; Santos, 1973). Examinando a coesão do PSD, da UDN, do PTB e do PSP nas votações nominais ocorridas ao longo do mandato de Juscelino Kubitschek, que guiou o país entre 1956 e 1960, Carvalho (1977) notou a preponderância de um padrão de colaboração entre oposição e situação. Isto porque os udenistas, formalmente alheios à coalizão governista, estiveram com mais frequência alinhados aos interesses da base de sustentação do presidente (PSD-PTB) do que em dissenso com a mesma. Na visão da autora, "o processo deliberativo consensual prevalecente entre as bancadas [teria sido] acompanhado pelo predomínio de entendimentos entre as facções políticas intrapartidárias" (Carvalho, 1977:57, ênfase minha). Santos (1973) levantaria indícios no mesmo sentido ao examinar deliberações nominais ocorridas no governo Goulart sobre matérias importantes naquela conjuntura. Os dados atestariam mudanças no comportamento partidário em função do núcleo das questões votadas, o que incidiria sobre as coalizões parlamentares, variando sua composição.

Pensando a primeira experiência democrática à luz de seus achados para o pós-1988, Figueiredo e Limongi $(1998,2007)$ concordam que conformações mais maleáveis, arquitetadas especialmente para o momento, parecem ter sido a norma durante a democracia de 1946, diferentemente do observado nos dias de hoje ${ }^{4}$. Os autores creditam a atual 
capacidade governativa do presidencialismo brasileiro à ampliação dos poderes legislativos do chefe do Executivo (iniciada no interregno militar) e à centralização decisória na Câmara em torno da Mesa Diretora e do Colégio de Líderes de 1989 em diante (Figueiredo e Limongi, 1998, 1999, 2007). O argumento se replicaria nas análises tecidas por Fabiano Santos (2003).

A grande oscilação na própria base formal de apoio ao Executivo no regime de 1946-1964 motivou mais especulações referentes à construção ad hoc desse suporte no Legislativo. No período, firmaram-se 19 coalizões de governo na Câmara, com duração média de 13 meses - excluída a curta interinidade exercida por Ranieri Mazzilli em setembro de 1961 (Figueiredo, 2008) ${ }^{5}$. Sabe-se que mais de um terço (para ser exata, $37 \%$ ) das mudanças na composição oficial delas deve-se ao calendário eleitoral regular, não decorrendo, portanto, de conflitos no interior da maioria (ibidem:195). Entretanto, também são conhecidos os potenciais motivos para indisposições entre integrantes da base governista. Wanderley Guilherme dos Santos já apontou que a UDN esteve na retaguarda do PTB em número de pastas ministeriais apenas durante as administrações JK e Goulart, conservando mais recursos de poder, enquanto se fazia "oposição", em comparação aos trabalhistas, quase sempre "situação" (Santos, W., 2003, cap. X). Essa situação amplia a suspeita em torno da possibilidade de barganha direta entre governo e setores udenistas na busca da contribuição necessária à passagem da agenda presidencial, uma vez ponderada a probabilidade da aliança PSD-PTB não se mostrar suficiente para a aprovação dessas políticas. O mesmo autor adverte, inclusive, ter sido esta a saída de praxe seguida pela maioria ao longo de todo o período - à exceção da administração Goulart, a única que poderia ter contado integralmente com uma coalizão formada apenas por pessedistas e trabalhistas para construir um governo estável (ibidem:275).

Outros estudos compartilhariam tese semelhante, supondo cruciais os assédios do governo à oposição, no acordo de colaboração legislativa, para o financiamento da governabilidade - com frequência, abalada (Amorim Neto e Santos, 2001; Santos, 2002). Chega-se até a se afiançar que as coalizões ad hoc seriam financiadas mediante a distribuição marginal de patronagem, quando se tratava de aprovar policy relevante (Santos, 2002). Mais do que isso: afirma-se que todos os presidentes do pré-1964 investiram nesta tática esperando criar uma "facção go- 
vernista" dentro das principais legendas da época para assegurar respaldo político no Congresso (Amorim Neto e Santos, 2001).

Implícita ou explicitamente, todas as leituras antecedentes presumem a dificuldade enfrentada pelo Executivo diante do desafio de estimar com precisão o tamanho de sua base de apoio no Legislativo, seja devido à falta de informações completas sobre a divisão de forças entre coalizão e oposição, seja em função do desconhecimento do grau de lealdade da sua própria base parlamentar. As interpretações incorporam, assim, o information effect de Riker (1962), assimilando a hipótese do contínuo descompasso entre as expectativas e a real força legislativa do governo ${ }^{6} \mathrm{sem}$, porém, enveredar no refino da alegada relação facciosismo-governabilidade. Responsáveis pela tentativa mais elaborada de discutir o problema, Amorim Neto e Santos (2001) reservaram-se a demonstrar que o presidente perdia apoio na Câmara com o decurso do seu mandato justamente pelo fato de se ver impossibilitado de assegurar a manutenção de favores às facções pró-Executivo aliciadas no seio da oposição ${ }^{7}$.

É verdade que os registros históricos não permitem reconstruir a composição integral das cisões intrapartidárias que emergiram durante a democracia de 1946. Sequer contamos com uma amostra estatisticamente razoável a ponto de viabilizar o teste perfeito do comportamento legislativo exibido pelas principais legendas de 1946-1964 e suas respectivas dissidências. Nem as sedições mais noticiadas pela literatura, a exemplo da Banda de Música udenista e das velhas Raposas que comandavam o PSD, foram listadas em detalhe pelos especialistas ${ }^{8}$. Todavia, pode-se deduzir o tamanho dessas cisões indiretamente, através do exame de dados agrupados por partidos - a mesma estratégia seguida pelos trabalhos pontuados acima. Para aprofundar o teste do facciosismo no pré-1964 e mensurar o efeito de rachas intrapartidários sobre a capacidade governativa da democracia de 1946, é importante sistematizar o desempenho legislativo do governo e apanhar a sua margem de (in)dependência frente às apregoadas composições ad hoc.

Este exercício pode ser operacionalizado através da crítica sumária das vitórias e derrotas do governo em votações nominais válidas ocorridas no plenário da Câmara dos Deputados sobre medidas cujo teor interessava ao situacionismo. Uma forma de apreender o referido interesse é classificar as matérias legislativas então deliberadas a partir de uma proxy baseada em dois conjuntos de proposições. O primeiro deles 
abarca as iniciativas legislativas do Executivo decididas no curso do próprio mandato do presidente que a rubrica. Isto porque, além de não soar razoável o dirigente do país despender energia apresentando projetos alheios ao seu interesse, vê-se que a maior parte dos tópicos sublinhados pela literatura como prioritários dentre os assuntos em pauta à democracia de 1946 abarca exatamente regulações oferecidas pelo Executivo Federal ${ }^{9}$. No Apêndice $B$ deste artigo há uma síntese dessas temáticas admitidas como centrais pela bibliografia especializada.

Perseguindo lógica semelhante, o segundo conjunto de medidas compreende as matérias assinadas por membros da coalizão em voga quando as questões seguem a deliberação. Isso inclui não somente as proposições elaboradas por deputados governistas individualmente, como também aqueles projetos organizados pelas comissões permanentes presididas por representantes de legendas alinhadas ao chefe do Executivo na Câmara. A categoria compreende, ainda, propostas assinadas pela Mesa Diretora da Casa, sempre que seu presidente estivesse filiado à situação. Desta vez, assume-se que este conjunto de políticas é importante para o governo como um todo.

Feitas tais ponderações, o sucesso do Executivo na Câmara pode ser capturado pela consagração da posição majoritária do partido do presidente no resultado final da votação nominal de matérias iniciadas por este Poder, à exceção das deliberações do gênero realizadas após a institucionalização da indicação de voto, definida pela Resolução no 71, em $1962^{10}$. Com a mudança, torna-se preferível tomar por referência a manifestação do líder da sigla que elegeu o dirigente do país. Por extensão do raciocínio, o êxito do governo na Casa em questões assinadas por membros da sua base parlamentar passa a ser apreendido em função da vitória, em plenário, da preferência majoritariamente configurada no interior da coalizão.

Sintonizada com todos os critérios discutidos, a Tabela 1 visa confrontar as previsões da literatura com os resultados políticos alcançados em plenário. Entre 1946 e 1964, ocorreram 1.465 votações nominais; $1.017(69,4 \%)$ delas foram consideradas válidas ${ }^{11} \mathrm{e}$, neste grupo, constam 692 que contemplaram matérias de interesse do situacionismo, cujos resultados seguem reportados.

Raras foram as ocasiões em que o governo viu os seus propósitos mitigados pelas preferências manifestas no parlamento durante votações nominais ${ }^{12}$. Nas decisões circunscritas às iniciativas do Executivo, $\mathrm{o}$ 
Tabela 1

Vitórias e Derrotas do Governo, por Coalizão, em Votações Nominais

(1946-1964)*

\begin{tabular}{|c|c|c|c|c|c|c|c|c|}
\hline \multirow{3}{*}{ Coalizão } & \multicolumn{7}{|c|}{ Vitórias e Derrotas do Governo } & \multirow{3}{*}{ Total } \\
\hline & \multicolumn{3}{|c|}{$\begin{array}{c}\text { Somente em Iniciativas } \\
\text { do Executivo }\end{array}$} & \multicolumn{4}{|c|}{$\begin{array}{c}\text { Em Iniciativas da sua Base } \\
\text { Parlamentar na Câmara }\end{array}$} & \\
\hline & V & $\mathrm{D}$ & Total & V & $\mathrm{D}$ & $\mathrm{SI}^{* *}$ & Total & \\
\hline Dutra II & 3 & - & 3 & 61 & 2 & 14 & 77 & 80 \\
\hline Dutra III & 13 & - & 13 & 19 & - & 1 & 20 & 33 \\
\hline Vargas I & 34 & 4 & 38 & 62 & 9 & 3 & 74 & 112 \\
\hline Vargas II & 26 & 4 & 30 & 91 & 7 & 1 & 99 & 129 \\
\hline Vargas III & - & - & - & 4 & - & - & 4 & 4 \\
\hline Café Filho II & - & - & - & - & - & 2 & 2 & 2 \\
\hline JK I & 39 & 3 & 42 & 140 & 7 & 7 & 154 & 196 \\
\hline JK II & 27 & - & 27 & 85 & 3 & 1 & 89 & 116 \\
\hline Quadros & - & - & - & - & 1 & - & 1 & 1 \\
\hline Goulart II & 1 & - & 1 & 1 & - & - & 1 & 2 \\
\hline Goulart IV & - & - & - & - & - & 2 & 2 & 2 \\
\hline Goulart V & 2 & - & 2 & 2 & - & - & 2 & 4 \\
\hline Goulart VI & 1 & 1 & 2 & 4 & - & 5 & 9 & 11 \\
\hline Total & $\begin{array}{c}146 \\
(92,4 \%)\end{array}$ & $\begin{array}{c}12 \\
(7,6 \%) \\
\end{array}$ & 158 & $\begin{array}{c}469 \\
(87,8 \%)\end{array}$ & $\begin{array}{c}29 \\
(5,4 \%) \\
\end{array}$ & $\begin{array}{c}36 \\
(6,7 \%) \\
\end{array}$ & 534 & 692 \\
\hline
\end{tabular}

Fonte: Banco de Dados Legislativos, Cebrap.

* Considera apenas votações válidas. Exclui duas deliberações incapazes de se calcular a posição do partido do presidente, porque tal legenda se dividiu - uma ocorrida em Vargas I e outra, em Quadros. A título de exposição, as coalizões que apresentam todas as caselas nulas serão omitidas nas tabelas.

** SI: Sem informação. Diz respeito a projetos de autoria de senadores e comissões mistas, desconsiderados na classificação das iniciativas da base parlamentar do governo na Câmara Federal.

êxito deste Poder ficou em torno de 90\% para o período 1946-1964, havendo coalizões que não amargaram uma única derrota em plenário na apreciação de matérias iniciadas pelo presidente. Com respeito às apreciações de questões interpostas pela sua base parlamentar de apoio na Câmara dos Deputados, o saldo positivo tem uma leve queda $(87,8 \%)$.

Nessa conjuntura, torna-se mais difícil dar por certa a visão convencional sobre a capacidade decisória da época depender da tendência dos presidentes em cortejar facções intrapartidárias que não compunham formalmente sua coalizão de forças no Legislativo. Dirimir essa aparente contradição é o propósito da Tabela 2, que informa como se cultivaram os resultados positivos observados acima. 
Facciosismo, Rachas Intrapartidários e Capacidade Decisória na Democracia...

Tabela 2

Tipos de Vitória do Governo, por Coalizão, em Votações Nominais (1946-1964)*

\begin{tabular}{|c|c|c|c|c|c|c|c|}
\hline \multirow{3}{*}{ Coalizão } & \multicolumn{6}{|c|}{ Tipo de Vitória } & \multirow{3}{*}{ Tota } \\
\hline & \multicolumn{3}{|c|}{$\begin{array}{c}\text { Somente em Iniciativas do } \\
\text { Executivo }\end{array}$} & \multicolumn{3}{|c|}{$\begin{array}{c}\text { Em Iniciativas da sua Base } \\
\text { Parlamentar na Câmara }\end{array}$} & \\
\hline & $\begin{array}{c}\text { Com a } \\
\text { Coalizão }\end{array}$ & $\begin{array}{l}\text { Com Ajuda } \\
\text { da Oposição }\end{array}$ & Total & $\begin{array}{c}\text { Com a } \\
\text { Coalizão }\end{array}$ & $\begin{array}{r}\text { Com Ajuda } \\
\text { da Oposição }\end{array}$ & Total & \\
\hline Dutra II & 3 & - & 3 & 61 & - & 61 & 64 \\
\hline Dutra III & 13 & - & 13 & 19 & - & 19 & 32 \\
\hline Vargas I & 32 & 2 & 34 & 53 & 9 & 62 & 96 \\
\hline Vargas II & 15 & 11 & 26 & 37 & 54 & 91 & 117 \\
\hline Vargas III & - & - & - & 4 & - & 4 & 4 \\
\hline JK I & 35 & 4 & 39 & 119 & 21 & 140 & 179 \\
\hline JK II & 25 & 2 & 27 & 78 & 7 & 85 & 112 \\
\hline Goulart II & 1 & - & 1 & 1 & - & 1 & 2 \\
\hline Goulart V & 2 & & 2 & 2 & - & 2 & 4 \\
\hline Goulart VI & 1 & - & 1 & 2 & 2 & 4 & 5 \\
\hline Total & $\begin{array}{c}127 \\
(87,0 \%)\end{array}$ & $\begin{array}{c}19 \\
(13,0 \%)\end{array}$ & 146 & $\begin{array}{c}376 \\
(80,2 \%)\end{array}$ & $\begin{array}{c}93 \\
(19,8 \%)\end{array}$ & 469 & 615 \\
\hline
\end{tabular}

Fonte: Banco de Dados Legislativos, Cebrap.

* Considera apenas votações válidas.

Os dados mostram que as contribuições da oposição eram residuais. Somente em Vargas II o auxílio externo teve importância efetiva para os objetivos do governo, chegando a determinar $65(55,6 \%)$ dos 117 resultados favoráveis estimados pelo grupo no poder. As iniciativas da base parlamentar de Getúlio na Câmara foram as que mais gozaram desse respaldo oposicionista, assegurando a vitória da posição majoritária da coalizão que o cercava em 54 (59,3\%) das 91 votações do gênero.

Esse conjunto de dados reflete, inclusive, decisões unânimes. Mantêlas no levantamento não é gratuito. Tais números demonstram que o governo se bastava em plenário para fazer valer as suas pretensões independentemente das contribuições da oposição, poucas vezes essenciais na passagem da agenda do Executivo. Estabelecendo o ponto de corte tradicionalmente empregado pela literatura para filtrar as votações nominais com real significância do ponto de vista do conflito partidário (qual seja, um mínimo de $10 \%$ dos parlamentares votando contra o resultado final), o sucesso do governo permanece predominante $^{13}$. Definitivamente, a norma era a vitória - e a vitória quase sem- 
pre assegurada pela própria base de apoio no Legislativo. Apenas em 17 ocorrências $(21,8 \%$ ) a situação necessitou da ajuda da oposição para aprovar as iniciativas do Executivo em decisões nominais válidas e não unânimes: trata-se de passagens em Vargas I (2 vezes) e II (9), além de registros em JK I (4) e II (2) ${ }^{14}$. Estendendo o raciocínio às matérias assinadas pelos membros da coalizão, esse percentual atinge meros $33,3 \%$ ( 89 de 268 casos).

A pergunta imediata que emerge desse quadro diz respeito ao entendimento das supostas facções potencialmente responsáveis por estremecer os maiores partidos de 1946-1964. Cabe chamá-las assim ou não passariam de históricos rachas intrapartidários que sublimavam ao momento das decisões em plenário? Seria apropriada a noção de facciosismo para a democracia de 1946?

\section{FACÇÕES PARTIDÁRIAS: DISCUSSÃO TEÓRICA E OPERACIONALIZAÇÃO DO CONCEITO}

A escassez de pesquisas relativas ao facciosismo não constitui exclusividade brasileira. Raros são os exames comparativos existentes. Além disso, os estudos disponíveis geralmente não se revelam capazes de "capturar dinâmicas de grupo e explicar o processo de mudanças", sobretudo porque se limitam a elaborar tipologias "baseadas em categorias de grupos subpartidários com diferentes características" (Boucek, 2009:2, tradução livre). Oferecem, antes, uma visão estática do facciosismo e, por extensão, respostas pouco convincentes às questões-chave de pesquisa, como o motivo de "alguns partidos políticos conterem facções enquanto outros não" (idem). Acredita-se que a ausência de uma agenda de pesquisa consolidada sobre o fenômeno se deva à própria conotação negativa que o termo "facção" assumiu desde sua origem, sendo por muito tempo empregado como sinônimo de "um grupo político empenhado em um facere perturbador e danoso", enquanto a ideia de "partido", transmitindo a ideia de parte, encerra um tom mais neutro, pois "a parte não é, em si, uma palavra depreciativa" (Sartori, 1983:24).

Os esforços mais recentes no sentido de abstrair o caráter valorativo normalmente imputado às facções para possibilitar o seu estudo estão contemplados na definição proposta por Verge e Gómez para o fenômeno. Essa noção foi adiantada na Introdução e constitui uma síntese das interpretações adotadas em outras fontes. De acordo com os 
autores, deve-se entender as facções como grupos intrapartidários que agem em conjunto visando metas comuns (Verge e Gómez, 2012:669) ${ }^{15}$. Seguindo a referida ideia, o propósito desta seção é averiguar a compatibilidade do comportamento dos partidos nas votações nominais ocorridas na Câmara dos Deputados entre 1946 e 1964 com o argumento corrente sobre o império de facções intrapartidárias no período.

Como apontado na seção anterior, as investigações dedicadas ao Brasil dos anos 1950 e 1960 afirmam o predomínio de coalizões legislativas ad hoc com base na dedução de cisões intrapartidárias em constante agitação na Câmara dos Deputados, a ver pela baixa coesão das legendas nas votações que ali tinham lugar. O ponto é que o facciosismo, per si, não implica necessariamente ausência de coesão legislativa. Embora se observe a recorrência de rachas ideológicos tanto no interior da maioria quanto da oposição, importa checar o impacto dessas divisões para a performance legislativa do governo. Dito de outra forma: endossar a tese das coalizões ad hoc enquanto padrão na democracia de 1946 perpassa pela comprovação de dois fatos. Primeiro, que a base de apoio ao governo não lhe creditava o imprescindível suporte nas deliberações em plenário ou a segurança necessária para evitar o cortejo do presidente do país e seus correligionários à oposição.

Segundo, é preciso constatar a existência de grupos que cederiam aos assédios do Executivo e com ele se comporiam justamente para assegurar o alcance de objetivos específicos, estabelecidos em função da própria conjuntura política. Neste caso, a hipótese da ascendência do facciosismo no período encontraria terreno se verificada a não adesão de determinadas dissidências no interior das legendas da coalizão governista ao programa situacionista e, na contramão, a colaboração de determinadas cisões, da oposição, ao plano de trabalho presidencial, com alguma sazonalidade. A questão temporal, assim, seria a proxy da unidade destas sedições intrapartidárias - grupos estratégicos para a administração da governabilidade.

No que diz respeito à primeira premissa, sobre o desempenho da base parlamentar do Executivo, já temos provas de que a coesão partidária daquela época era menor em relação à experiência democrática atual. Uma série de levantamentos reitera este diagnóstico, retratando as taxas médias do índice de Rice apresentadas pelos maiores partidos da democracia de 1946 abaixo de 70,0, independente da origem da matéria sob votação nominal (Figueiredo e Limongi, 1998; Santos, 1997, 
2002, 2003; Santos, W., 2003 ${ }^{16}$. A questão é que isto não constitui demonstração suficiente do descompromisso da maioria para com a agenda presidencial - a exemplo dos saldos políticos substantivos revelados na seção precedente.

Também não há comprovação empírica sistemática da vigência da segunda condição do facciosismo na democracia de 1946 - isto é, a observância de cisões legislativas intrapartidárias capazes de serem mobilizadas tão logo se fizessem imprescindíveis conformações ad hoc. Até agora, a literatura disponível proveu somente a hipótese, registrando as dificuldades de o Executivo consolidar compromissos duráveis no Congresso Nacional e as razões que fomentariam a emergência dessas facções (Benevides, 1981a, 1981b; D'Araújo, 1992; Skidmore, 1975).

Um novo exercício baseado nos mesmos dados trabalhados anteriormente pode iluminar o ponto, complementando a análise já encaminhada na seção precedente. Desta vez, parece oportuno checar se as vitórias governistas que só se materializaram graças às contribuições de opositores redundaram de rachas intrapartidários ocasionais ou duradouros em ambos os lados (ou seja: de coalizão e não coalizão divididas). O passo a passo para a execução da ideia segue descrito. Numa primeira etapa, perpassa pelo confronto dos votos dados no seio da própria coalizão vigente ao tempo das referidas deliberações com a ajuda numérica daqueles que não se alinhavam com o governo, ao menos formalmente. Nessa perspectiva, a diferenciação do comportamento dos membros da coalizão se baseia na noção de indisciplina, pensada como toda manifestação parlamentar contrária aos interesses do situacionismo. Daí a opção de recorrer ao estudo desagregado das mesmas votações para verificar a regularidade de possíveis correntes agindo de modo independente tanto no interior do governo quanto na própria oposição.

Comecemos pela crítica dos resultados por partidos e coalizões observados naquelas 17 votações relativas a iniciativas do Poder Executivo que só foram aprovadas com a ajuda de deputados de fora da sua base parlamentar de apoio na Câmara Federal. Para facilitar a compreensão da Tabela 3, que sistematiza a primeira etapa do referido teste, cabe a apresentação das variáveis coluna a coluna. As três primeiras codificam as votações, respectivamente, segundo a coalizão em que ocorreram, a data de realização e a maioria simples (pois a maioria qualificada não era exigida em nenhuma dessas 17 deliberações). No caso de 
Vargas, eram necessários 78 votos para que os projetos considerados fossem aprovados. Caso contrário, a decisão estava adiada. Em JK, esse número sobe para 83.

A quarta coluna da tabela indica a posição majoritária do partido do presidente em função do universo de deliberações estudado neste momento - as iniciativas do Executivo. Conforme foi discutido acima, a preferência do governo nessas matérias foi deduzida a partir da manifestação que se fez maior no seio da legenda que elegeu o dirigente do país. A adesão da base parlamentar à referida escolha governista pode ser conferida nas colunas seguintes, que dividem cada um dos partidos-membros da coalizão em dois subgrupos: os disciplinados, que votaram com o governo, são somados na categoria $\mathrm{nD}$, e os indisciplinados, na nI.

Por fim, as últimas colunas totalizam i) os votos disciplinados da base do governo em cada votação; ii) os números da indisciplina no interior da coalizão; iii) a soma de ambas as preferências observadas; iv) o número de votos que faltaram para a coalizão vencer com as suas próprias forças; e v) a soma das contribuições da oposição, nesta ordem.

Os dados realmente revelam a dispersão dos quadros partidários. Para além dos pessedistas, com uma tendência maior à concentração de votos numa determinada posição, todas as demais legendas denotam a dificuldade de compor maiorias internamente. Em contrapartida, a ajuda dos oposicionistas sinaliza, a princípio, para a sistematicidade. Contribuições de fora da base se mantêm praticamente sempre elevadas, em número muito superior ao que se fazia imprescindível para o governo.

Procedendo ao exame desagregado de cada uma dessas decisões para contemplar, entretanto, a autoria do subsídio externo, observa-se que as manifestações dos filiados à UDN constituíram a base, por excelência, do êxito do Executivo na Câmara dos Deputados durante a vigência de duas coalizões. É o que mostra o Gráfico 1 contrastando a média do número total de votos oriundos das legendas alheias à base parlamentar de apoio ao Executivo diferenciando-se aqui as contribuições da bancada udenista nas 17 votações críticas, válidas e não unânimes. Para todas as coalizões, as barras em branco mostram o número médio de votos oposicionistas necessários para a vitória do governo. Já as barras em cinza apresentam o número médio das contribuições dos udenistas, enquanto as em preto divulgam o número médio do apoio oriundo de outros partidos de oposição. 
Jaqueline Porto Zulini

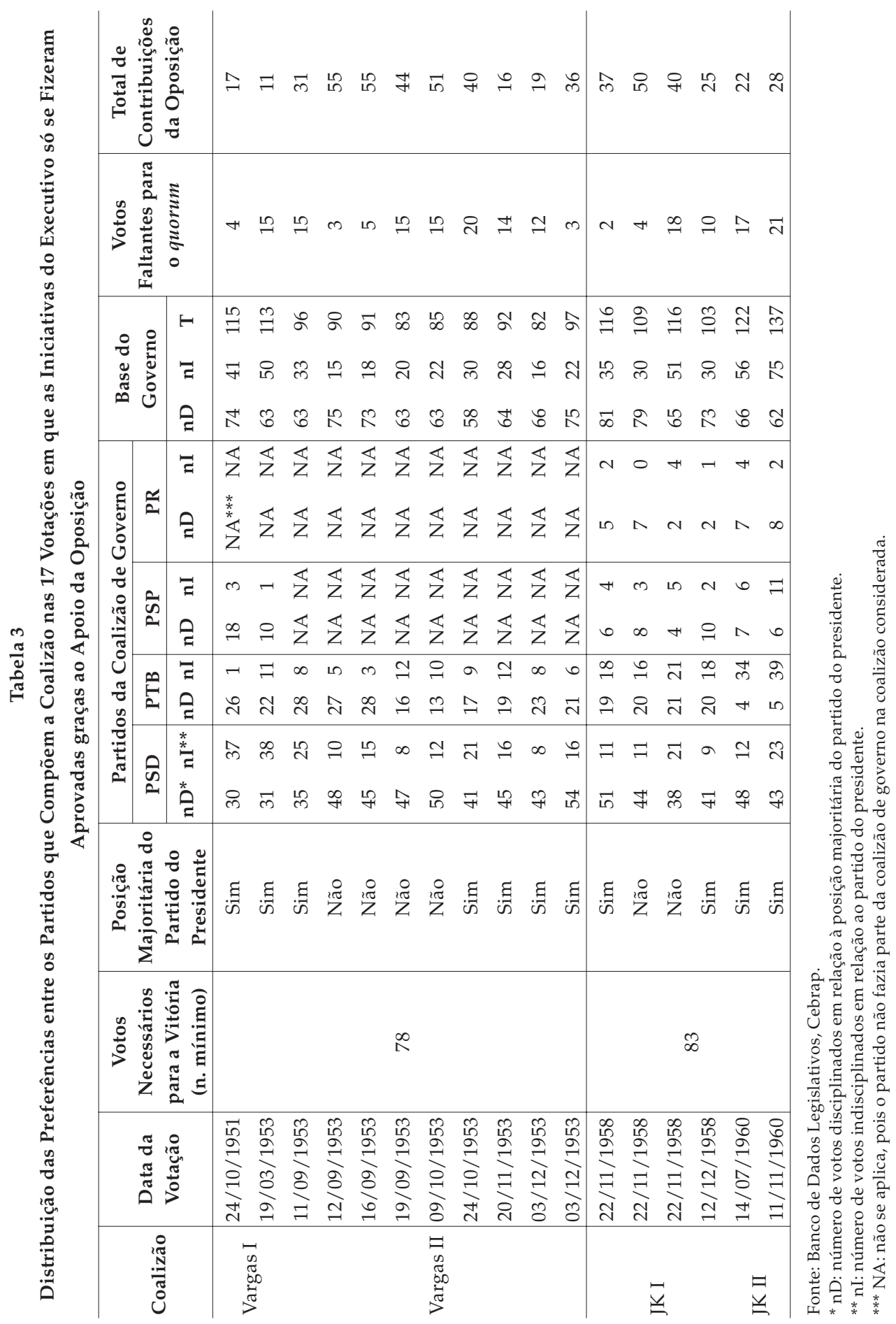

1030 DADOS - Revista de Ciências Sociais, Rio de Janeiro, vol. 58, no 4, 2015 
Facciosismo, Rachas Intrapartidários e Capacidade Decisória na Democracia...

\section{Gráfico 1}

Contribuição Média de Setores da Oposição em Votações Válidas e Não Unânimes sobre Matérias Iniciadas pelo Executivo, Vitorioso com a Ajuda da Oposição

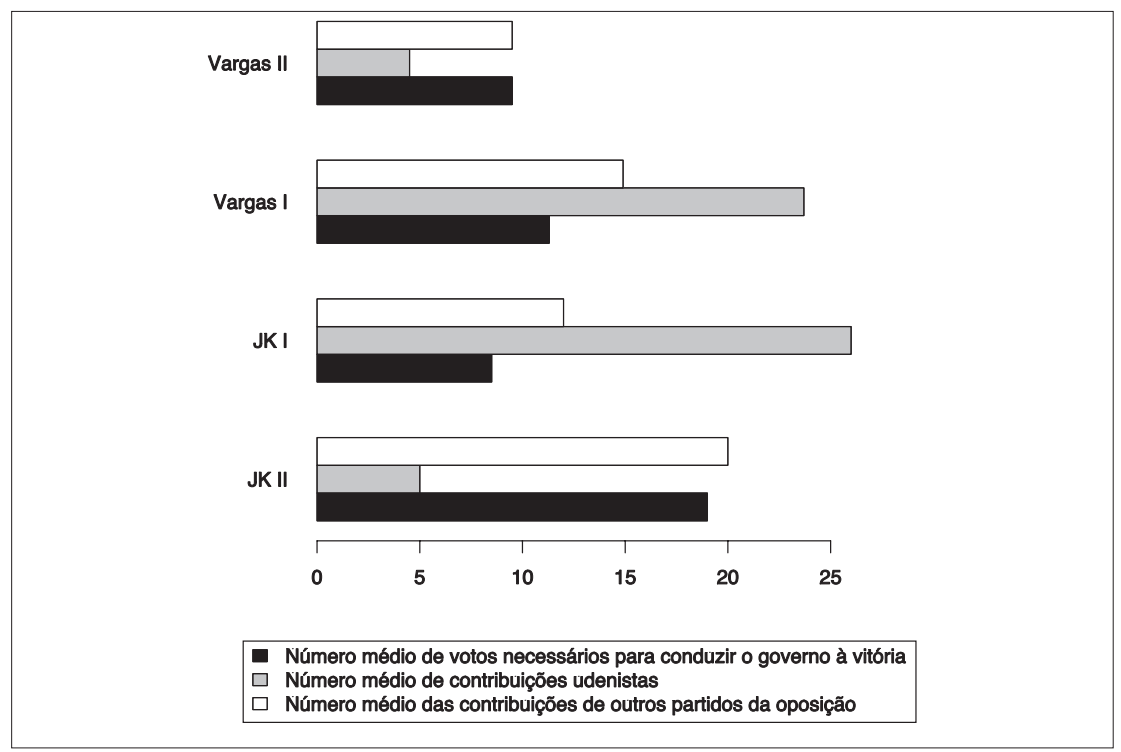

Fonte: Banco de Dados Legislativos, Cebrap.

Como se vê, a UDN ultrapassaria os demais partidos de oposição em número de votos favoráveis à situação no poder em Vargas II e JK I, quando a base parlamentar de apoio ao Executivo na Câmara não se mostrava capaz de assegurar, por si só, a vitória da posição estimada pelo governo nas decisões em andamento no plenário.

Todavia, o exame qualitativo de cada uma dessas decisões não aponta a regularidade dos parlamentares em seu auxílio ao governo. Os udenistas que dirigiam esses votos capitais para o situacionismo variavam conforme as votações se seguiam. Não há como se comprovar, pelos dados, a agência de grupos específicos agindo em plenário. Afinal, o conceito de facciosismo requer alguma sazonalidade para se fazer inquestionável.

As constatações precedentes se mantêm na análise das 89 decisões válidas e não unânimes relativas a matérias iniciadas por membros da base governista na Câmara que dependeram do socorro da oposição para serem aprovadas, omitidas por falta de espaço. Com efeito, o impasse em construir maiorias dentro dos próprios quadros é uma realidade para os partidos da coalizão presidencial no parlamento e o apoio 
dos udenistas se destaca na conquista dos saldos tencionados pela situação. Apenas sob Vargas II haveria um grupo de deputados udenistas que votaria sistematicamente com o governo. No geral, a capacidade governativa à democracia de 1946 independeu do socorro de setores oposicionistas nas votações nominais então ocorridas.

\section{COMO SE CONSTRUÍAM MAIORIAS LEGISLATIVAS NA DEMOCRACIA DE 1946 ?}

Os dados apresentados nas seções anteriores são contraintuitivos consideradas as visões correntes da literatura sobre a capacidade governativa do Brasil no pós-guerra. Via de regra, o decision-making é considerado constrangido tanto pela prevalência de facções intrapartidárias que minariam a base de apoio ao governo no Legislativo quanto pelo seu caráter descentralizado quando comparado ao período atual. Assume-se a dispersão do poder na Câmara dos Deputados, sobretudo em função da inexistência do Colégio de Líderes, como expressão do papel secundário das lideranças, que se revelariam incapazes tanto de centralizar o processo decisório quanto de coordenar suas respectivas bancadas (Amorim Neto e Santos, 2001; Santos, 2002; Figueiredo e Limongi, 1998, 2007). Entretanto, a própria dinâmica deliberativa vigente na democracia de 1946 inclui dispositivos que poderiam acionar a mobilização de divisões intrapartidárias, em que pese a possibilidade de cisões intrapartidárias, bem como as coalizões, se reunirem ad hoc.

Completando o turno regimental da discussão, a votação das proposições examinadas na Câmara Federal durante 1946-1964 consumava-se por maioria de votos, presente a maior parte dos membros da Casa, salvo a existência de disposição constitucional em contrário ${ }^{17}$. A deliberação podia se dar por três processos distintos: o simbólico, o nominal e o de escrutínio secreto. Como o nome sugere, o último preservava o resultado da decisão, executada por meio de cédulas depositadas em urnas, cujo saldo entrava para os anais apenas nas vagas categorias "não houve votação", "aprovada" ou "adiada" - tal qual acontece nos dias de hoje. Em certa medida, a votação simbólica também resguardava o anonimato dos parlamentares, que eram convidados pelo presidente da sessão a se levantarem caso condenassem a proposição em debate, enquanto os favoráveis permaneceriam sentados - posição supostamente inicial de todos os presentes. Seguia-se a proclamação do resultado manifesto dos votos e, para fins de minuta, o registro nas publica- 
ções oficiais lançava apenas a posição sufragada pelo plenário, como também prevê o Regimento Interno da Câmara dos Deputados (RICD) em vigor atualmente.

Já a opção nominal expunha abertamente os legisladores, que eram chamados em voz alta pelo primeiro-secretário, respondendo sim ou não conforme fossem a favor ou contra o que se estivesse votando (Resolução no 10, de 1947, art. 119, § 3ㅇ). Dois outros secretários anotavam os parlamentares que votassem num, ou noutro sentido, proclamando em voz alta o resultado da votação à medida que o primeiro-secretário fizesse a chamada $\left(\S 4^{\circ}\right)$. Uma vez encerrada a votação, o diretor dos trabalhos legislativos anunciava o resultado final, mandando ler em seguida os nomes dos que votaram sim e os dos que votaram não (§ $5 \circ$ ), posteriormente disponibilizados na lista reproduzida pelos Diários da Casa, de livre acesso. Mais uma vez, nenhuma novidade no confronto com a regra presente - a não ser pela automação do processo, que agora substitui o trabalho manual e oral dos secretários da Mesa Diretora pela instantaneidade do painel eletrônico.

Decerto, a grande diferença entre os procedimentos decisórios adotados em cada experiência democrática, então sonegada pela literatura, diz respeito precisamente ao pedido de verificação da votação, facultado na existência de dúvida quanto ao saldo divulgado pelo presidente. No período 1946-1964, o processo de checagem dos votos não seguia diretamente a fórmula nominal, como se faz atualmente. Existia uma verificação de quorum preliminar, que só redundava em chamada nominal na ausência de número legal.

Qualquer deputado poderia questionar o saldo da deliberação sinalizado pela Mesa. Até a publicação da Resolução no 582, de 1955, o pedido de verificação era imediatamente acolhido, não sendo necessário apoiamento mínimo para ser deferido. Já a partir da sanção desse texto, a checagem do resultado passou a depender da adesão de pelo menos 20 deputados para ser assegurada ${ }^{18}$.

Basicamente, a verificação consistia na contagem dos votos, que se faria por bancadas, isto é, por filas de poltronas do recinto, uma a uma ${ }^{19}$. O presidente deveria convidar os deputados favoráveis à matéria em debate a se levantarem, enquanto o primeiro-secretário anunciaria, em voz alta, o resultado parcial obtido em cada bancada ou fileira, à medida que se fizesse a checagem. Da mesma forma se procederia na contagem dos votos contra. Finalmente, o resultado total apurado seria 
anunciado (Resolução no 10, de 1947, art. 129, § 2). Na hipótese de a votação indicar ausência de número, o regimento determinava a realização da chamada dos deputados, que se faria como votação nominal da matéria em deliberação, salvo se, pelo adiantado da hora, ou por ser vi-

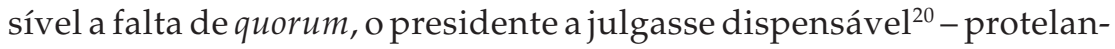
do a decisão para a ordem do dia seguinte, mas sem nenhuma garantia de recolocá-la, de fato, a votos.

Do exposto depreendem-se três notas relevantes. A primeira delas é que, na prática, a contagem dos votos por fileiras de poltronas no plenário, da forma como se dava, aumentava o custo político da deliberação, deixando o parlamentar numa situação difícil - e muito semelhante à enfrentada na votação nominal. Diversamente da discrição típica da decisão simbólica, fundada numa ação grupal que facilitava a mesclagem dos votos individuais, ainda protegidos no domínio público via mera divulgação do resultado final, as verificações de quorum partilhavam do desconforto causado pela supressão do anonimato durante o processo decisório - incômodo intrínseco às deliberações nominais. Basta pensar que ambas expunham os deputados entre si, abrindo espaço para o teste dos compromissos assumidos pelos congressistas, sejam acordos de natureza eleitoral ou partidária ${ }^{21}$.

Extensão do raciocínio anterior, a segunda observação importante é que a verificação de quorum, justamente por configurar uma eventual intermediação entre o método nominal e a votação simbólica, poderia assumir rótulo preliminar. Parece plausível cogitar que uma série de checagens de resultado, todas abaixo do número legal, fosse estrategicamente manipulada a fim de servir como termômetro do plenário. Isto porque as prévias sinalizariam as preferências dos legisladores em parciais reveladoras tanto para líderes partidários acompanharem $o$ comportamento de seus respectivos quadros - e as cisões neles desenhadas - quanto para o governo avaliar a conduta e a força relativa da sua base de apoio, confrontando-as com a mobilização aparente da oposição.

Por fim, a última ressalva concentra-se no fato de as decisões legislativas tecidas entre 1946 e 1964 dependerem, a princípio, da predisposição de um único ator, capaz de fazer uso da própria proteção regimental para subjugar o decision-making aos auspícios de suas paixões pessoais ou aos negócios de quem ele defendesse. Coordenando a fase final do processo deliberativo, o presidente das sessões no plenário era 
capaz de condicionar, na prática, os resultados em benefício do governo. Na incapacidade de negar petições do gênero ${ }^{22}$, sua margem de manobra era favorecida pela própria observação das parciais divulgadas pelas verificações de quorum, que funcionavam como verdadeiros "placares" ad hoc, boas referências para se calcular o melhor timming à apreciação das proposições prontas para votação - cuja ordenação ficava, por determinação regimental, a encargo da Mesa.

Essa leitura soa mais palpável quando lembramos que todos os presidentes da Casa eram alinhados ao pessedismo ${ }^{23}$. Desse modo, a ampla margem de independência do presidente da Câmara Federal no desenrolar das votações em plenário emerge como verdadeira delegação da vontade da maioria dos legisladores. Não fosse assim, os artigos regimentais que asseguravam ao diretor das sessões na Câmara ampla margem de manobra na condução das deliberações na Casa certamente seriam alterados, a fim de deslegitimar as ações discricionárias então garantidas ao arbítrio daquele ator pelo próprio texto norteador dos trabalhos legislativos - o regimento interno. No entanto, as referidas regras mantiveram-se inalteradas por todo o período. Isto significa que, do modo como a tomada de decisão estava institucionalizada, a liberdade do presidente da Mesa Diretora não se afigurava acima dos partidos representados em plenário, mas constituía uma "concessão" das legendas. Isto não equivale a dizer que o decision-making fosse incólume a disputas naquela época. Significa apenas que a simpatia da Mesa, na prática sempre dirigida pela maioria, era especialmente relevante naquela conjuntura.

Supondo a prevalência dos rachas intrapartidários na democracia de 1946, a regulação regimental em torno da verificação de quorum assume, consequentemente, caráter investigativo destacado. Já foi dito que a literatura frisa a limitação do governo em calcular perfeitamente o tamanho de sua real coalizão de apoio no Congresso por causa da baixa coesão partidária verificada durante 1946-1964. Em tese, uma dificuldade que motivaria os assédios do Executivo à oposição, aproveitando-se das divisões intrapartidárias existentes em seu seio para angariar as cabeças faltantes e reunir um grupo de respaldo legislativo mínimo, capaz de aprovar as medidas pretendidas. Neste quadro, a checagem de número se eleva como um instrumento de factível potencial tático no contorno do impasse. Viabilizando a medição do poder de cada bancada em plenário, a verificação de quorum mostrava-se um atalho informacional para a definição da estratégia aparentemente 
mais conveniente na busca dos resultados visados no próprio desenrolar da votação, inclusive a reacomodação dos deputados se necessário fosse.

Assim, o controle exercido pelo presidente da Mesa sobre o decisionmaking na democracia de 1946 igualmente se torna uma proxy central para este artigo. É importante mensurar a discricionariedade do diretor dos trabalhos legislativos, já que grandes eram os motivos para a sua atuação se orientar em consonância aos interesses da maioria, sabiamente a grande controladora deste posto estratégico. Daí a performance deste ator nortear o foco da análise subsequente.

\section{A DISTRIBUIÇÃO DAS VERIFICAÇÕES DE VOTAÇÃO EM 1946-1964}

Estudos sobre a experiência norte-americana denunciam a transação de votos justamente no desenrolar das deliberações. King e Zeckhauser (2003) demonstram a capacidade de os líderes coordenarem a ação dos parlamentares, sobretudo em votações apertadas. O trabalho evidencia a existência de uma margem de votos negociáveis, que seriam objeto de especial atenção quando o resultado da decisão se asseverasse demasiado incerto ${ }^{24}$. Saiegh (2011) ratifica a tese, apontando a postura eventual de alguns deputados, que ficariam observando as parciais da votação, manifestando-se apenas momentos antes da preferência majoritária ser definida, ou mesmo retificando o voto já expresso ao início da deliberação, caso fosse assim acertado no decorrer do processo. Nestes termos, as variações nas taxas de produção legislativa derivariam das diferenças de incerteza sob o plenário, e não de apoio partidário. Dito de outro modo: o sucesso legislativo dependeria da previsibilidade do comportamento de legisladores com direito a voto e da viabilidade da compra de votos.

Tendo em mente essas referências, o esforço que será realizado a partir de agora recorre ao exame crítico das verificações de votação realizadas na Câmara dos Deputados durante a democracia de 1946 assumindo que o estatuto da checagem de quorum potencializa, por definição, a estrutura de incentivos para essa coordenação e reacomodação de votos no plenário. A Tabela 4 totaliza os dois tipos de verificação de votação (checagem de quorum + decisão nominal) deferidos entre 1946 e 1964. Nada menos do que 1.729 checagens de decisões primárias foram aceitas pelo presidente da sessão plenária, relativas a 686 matérias de cunho distinto, entre votações de projetos e procedimentos. 
Facciosismo, Rachas Intrapartidários e Capacidade Decisória na Democracia...

Tabela 4

Distribuição das Verificações de Votação, por Coalizões

(1946-1964)*

\begin{tabular}{l|c|c|c}
\hline Coalizão & $\begin{array}{c}\text { Votações } \\
\text { (n) }\end{array}$ & $\begin{array}{c}\text { Duração da Coalizão } \\
\text { (em meses) }\end{array}$ & $\begin{array}{c}\text { Média de Votações } \\
\text { oo Mês }\end{array}$ \\
\hline Dutra II & 272 & 42 & 6,5 \\
Dutra III & 36 & 10 & 3,6 \\
Vargas I & 121 & 28 & 4,3 \\
Vargas II & 152 & 12 & 12,7 \\
Vargas III & 11 & 3 & 3,7 \\
Café Filho I & 102 & 5 & 20,4 \\
Café Filho II & 58 & 9 & 6,4 \\
N. Ramos & 62 & 3 & 20,7 \\
JK I & 518 & 36 & 14,4 \\
JK II & 247 & 24 & 10,3 \\
Quadros & 37 & 7 & 5,3 \\
Ranieri Mazzili & 4 & $0 * *$ & - \\
Goulart I & 4 & 9 & 4,0 \\
Goulart II & 65 & 2 & 7,2 \\
Goulart III & 6 & 4 & 3,0 \\
Goulart IV & 4 & 4 & 1,0 \\
Goulart V & 7 & 6 & 3,8 \\
Goulart VI & 22 & 3 & - \\
Goulart VII & 1 & & 3,3 \\
\hline Total & & 9 &
\end{tabular}

Fonte: Banco de Dados Legislativos, Cebrap.

* Considera tanto as verificações de votação sobre projetos quanto sobre procedimentos regimentais.

** Esta coalizão amargou meros 13 dias de duração.

Os dados indicam que os deputados tiveram seus votos conhecidos pelos seus pares sobretudo no governo Kubitschek, quando se registra a maior incidência de ambos os mecanismos decisórios, isto é, as checagens de quorum e as deliberações nominais propriamente ditas - nomes distintos para praxes de magnitude quase idêntica. Somente em JK I localizam-se nada menos do que $518(30,0 \%)$ das 1.729 verificações de votação concedidas ao longo de todo o pré-1964²5. Em números absolutos, as coalizões Dutra II (272), JK II (247), Vargas I (121) e II (152) e Café Filho I (102) também se destacam pela elevada recorrência desse instrumento regimental, todas com montantes, no mínimo, de ordem centenária. Ponderando, porém, o total acumulado em cada coalizão pela 
sua duração correspondente, em meses, surpreende a frequência com a qual os deputados foram submetidos a deliberações constrangedoras, responsáveis pela revelação individual de seus votos, em composições políticas dissolvidas rapidamente. Em relevo, constam Café Filho I e Nereu Ramos, com médias de verificação de votação consideravelmente altas para o tempo em que vingaram - meros 156 e 80 dias, respectivamente ${ }^{26}$.

Para esclarecer o quanto os governos da democracia de 1946 possam ter sofrido com os rachas intrapartidários no plenário da Câmara, o passo subsequente é decifrar a lógica da conformação de resultados políticos substantivos no Parlamento. Em tese, as verificações de votação emergem, dentre o rito ordinário de apreciação e deliberação das matérias, como termômetro da divisão de forças partidárias. Daí ser relevante checar, em primeiro lugar, se os pedidos de verificação de votação eram apropriados de modo estratégico tanto pela oposição quanto pela própria situação. Teoricamente, maioria e minoria poderiam se valer do emprego tático desse instrumento regimental, ainda que para propósitos totalmente assimétricos. De um lado, partidos alheios à base formal de governo estariam habilitados a propor revisões de votação para dificultar os trabalhos em plenário e, mesmo, emperrar a pauta do Congresso. A situação, por seu turno, também contaria com a chance de se aproveitar das verificações de quorum para medir sua força efetiva e coagir os seus a se manifestarem em favor dos interesses do governo, quando não mesmo acelerar contato com membros da oposição, caso houvesse como cativá-los. Se realmente existiam opções de voto a serem barganhadas pelos aliados do presidente mediante negociação com cisões intrapartidárias adversárias, conforme a necessidade, tal qual a literatura tanto apregoa, não haveria melhor oportunidade para se conhecerem as posições de todos os parlamentares, visualizar desertores e potenciais aliados.

Quando se sistematizam as autorias dos pedidos de verificação de votação concedidos em 1946-1964 a fim de testar se o argumento prévio procede, constata-se o predomínio de iniciativa da oposição, responsável por $68,9 \%$ das solicitações deferidas durante todo o período contra $29,6 \%$ de requerimentos pleiteados por membros da coalizão ${ }^{27}$. Este dado não varia muito quando desagregado pelas iniciativas das questões em apreciação e tampouco causa surpresa ${ }^{28}$. Oposicionistas normalmente empregam diversos mecanismos procedimentais tanto para comprometer o ritmo decisório no parlamento como para reafir- 
mar as próprias bases programáticas perante o eleitorado, embora tenham ciência da impossibilidade de contar com o endosso do plenário na aprovação das causas em questão ${ }^{29}$.

Assumir que o potencial informacional das verificações de votos era capitalizado também pelo governo pressupõe constatar algumas condições elementares. São elas:

Condição I-A origem das verificações de votos. O uso estratégico deste instrumento será apreendido somente se o mecanismo constar enquanto produto de solicitações de checagem do resultado da votação primária (e não decorrentes de requerimentos para decisões nominais diretas).

Condição II - O saldo das verificações de quorum. A emergência de um padrão de verificações de quorum inválidas - isto é, aquelas sem número legal e, portanto, incapazes de decidir a votação em andamento, igualmente indicaria sua apropriação estratégica. Afinal, a não decisão daria margem para que o jogo político pudesse se desenrolar nesse breve gap temporal entre um mecanismo decisório e outro.

Condição III - A influência do presidente da Câmara no processo decisório. Uma conduta discricionária do diretor dos trabalhos na Casa durante as verificações de votação também sinalizaria o espaço aberto a estratagemas políticos variados pelo método de checagem dos saldos legislativos em jogo.

Passemos à análise empírica de cada uma destas três condições. A primeira premissa encontra suporte nos dados. Quase $90 \%(89,2 \%)$ das vezes o método nominal advém das checagens de votação deferidas na Câmara dos Deputados ao longo de todo o pré- $1964^{30}$. Em todas as coalizões, sem exceção, as verificações de deliberações contestadas configuraram a razão, por excelência, daquele procedimento decisório.

Também a segunda condição é satisfeita. Definitivamente, a checagem de quorum não era decisiva. Pouco mais de 15\% (17,5\%) delas hesitava em termos de solução efetiva das matérias em análise pelo plenário, atingindo número legal. A norma era a ausência de manifestações suficientes para sufragar uma escolha final, cuja frequência beirava os dois terços das observações no pré-1964 (63,4\%), com algumas oscilações no estudo desagregado por coalizões ${ }^{31}$.

Por fim, permanece a suspeita em torno da postura predominantemente discricionária do presidente da Câmara dos Deputados na condução 
do processo decisório (terceira condição). A discricionariedade foi medida a partir daquelas ocasiões em que o diretor da Mesa adiou uma verificação de votação quando a checagem de quorum revelou a inexistência de número legal como, ainda, todas as vezes nas quais sua escolha foi no sentido inverso - isto é, pelo prosseguimento da deliberação via chamada nominal. Em contrapartida, se considerou isento o procedimento do grande fiscal dos trabalhos na Casa nas demais situações, que abrangem desde a conclusão de votações na verificação de quorum, decididas por existência de número, até os casos de retirada do pedido de renovação da deliberação pelo próprio requerente. Os números sinalizam o predomínio da suposta arbitrariedade do presidente da Câmara no exercício de sua função, aparentemente decisiva em mais de $60 \%(63,4 \%)$ das observações sintetizadas no teste da terceira condição. Somente em algumas coalizões essa conduta se atenuaria ${ }^{32}$. Fica limitada qualquer ponderação maior sobre o peso dessa aparente discricionariedade em virtude de restar desconhecida a soma dos pedidos de verificação indeferidos entre 1946-1964.

De todo modo, quando se correlaciona o uso da verificação de quorum com os resultados políticos substantivos alcançados pelo governo em plenário, a ideia de que este procedimento facilitava a coordenação da base ganha força. Constitui justamente a proposta da Tabela 5 cruzar os tipos de vitória do governo com as checagens das deliberações deferidas entre 1946 e 1964.

Tabela 5

Tipos de Vitória do Governo, por Coalizão, segundo a Escolha Procedimental, em Votações Nominais de Matérias Iniciadas pelo Executivo

(1946-1964)*

\begin{tabular}{l|c|c|c|c|c}
\hline Coalizão & \multicolumn{4}{|c|}{ Tipo de Vitória } & Total \\
\hline & \multicolumn{2}{|c|}{$\begin{array}{c}\text { Com os Membros da } \\
\text { Coalizão }\end{array}$} & \multicolumn{2}{c}{$\begin{array}{c}\text { Com a Ajuda da } \\
\text { Oposição }\end{array}$} & \\
\hline & $\begin{array}{c}\text { Verificação } \\
\text { de Quorum } \\
\text { Prévia }\end{array}$ & $\begin{array}{c}\text { Chamada } \\
\text { Nominal } \\
\text { Direta* }\end{array}$ & $\begin{array}{c}\text { Verificação } \\
\text { de Quorum } \\
\text { Prévia }\end{array}$ & $\begin{array}{c}\text { Chamada } \\
\text { Nominal } \\
\text { Direta }\end{array}$ & \\
\hline Dutra II & 3 & - & - & - & 3 \\
Dutra III & 13 & - & - & - & 13 \\
Vargas I & 32 & - & 2 & - & 34 \\
Vargas II & 14 & 1 & 8 & 3 & 26 \\
\hline \multicolumn{7}{r}{} & \multicolumn{7}{r}{} & & & (continua)
\end{tabular}


Facciosismo, Rachas Intrapartidários e Capacidade Decisória na Democracia...

(continuação)

\begin{tabular}{|c|c|c|c|c|c|}
\hline \multirow{3}{*}{ Coalizão } & \multicolumn{4}{|c|}{ Tipo de Vitória } & \multirow{3}{*}{ Total } \\
\hline & \multicolumn{2}{|c|}{$\begin{array}{c}\text { Com os Membros da } \\
\text { Coalizão }\end{array}$} & \multicolumn{2}{|c|}{$\begin{array}{c}\text { Com a Ajuda da } \\
\text { Oposição }\end{array}$} & \\
\hline & $\begin{array}{c}\text { Verificação } \\
\text { de Quorum } \\
\text { Prévia }\end{array}$ & $\begin{array}{c}\text { Chamada } \\
\text { Nominal } \\
\text { Direta* }^{*}\end{array}$ & $\begin{array}{c}\text { Verificação } \\
\text { de Quorum } \\
\text { Prévia }\end{array}$ & $\begin{array}{c}\text { Chamada } \\
\text { Nominal } \\
\text { Direta }\end{array}$ & \\
\hline JK I & 27 & 8 & 3 & 1 & 39 \\
\hline JK II & 13 & 12 & 2 & - & 27 \\
\hline Goulart II & 1 & - & - & - & 1 \\
\hline Goulart V & 2 & - & - & - & 2 \\
\hline Goulart VI & - & 1 & - & - & 1 \\
\hline Total & 105 & 22 & 15 & 4 & 146 \\
\hline
\end{tabular}

Fonte: Banco de Dados Legislativos, Cebrap.

* Considera apenas votações válidas. Inclui tanto casos de passagem da lista sem justificativa prévia quanto observações do emprego do método nominal sob o argumento da visível falta de número, além das votações deliberadas por esta via procedimental em virtude da aprovação de requerimentos que a solicitavam.

Os dados são sugestivos. A maioria das vitórias do governo apenas com a ajuda da própria base parlamentar em decisões nominais foi precedida de verificação de quorum. Isto sinaliza para a existência de mecanismos de negociação capazes de coordenar as rivalidades intrapartidárias na época em benefício da governabilidade.

\section{CONSIDERAÇÕES FINAIS}

Seja em estudos de casos, seja em análises mais gerais, o panorama normalmente delineado pela literatura apresenta a governabilidade na democracia de 1946 como uma preocupação contínua do Poder Executivo. Os analistas afirmam que a desconfiança inerente à coesão da coalizão de apoio do presidente no Legislativo levaria o dirigente do país a barganhar, com frequência, os votos das várias cisões existentes no seio da oposição para reunir a sustentação parlamentar necessária.

Os exercícios empíricos desenvolvidos neste artigo não pretendem questionar a existência dos rachas intrapartidários no Brasil do pósguerra. Basta o estudo individual de cada uma das votações nas quais a preferência do governo não encontrou respaldo na sua própria base de sustentação no Legislativo para observarmos problemas de coordenação de maiorias no seio dos próprios partidos de coalizão. A questão é a irregularidade das observações, que acaba por comprometer o emprego do próprio conceito de facção ao período como um todo. 
No limite, o sobredimensionamento do problema se eleva como uma dificuldade geral dos pesquisadores em admitir o caráter positivo do dinamismo político vivido na República de 1946, que não estava fadada, desde sua origem, ao fracasso. Via de regra, os trabalhos disponíveis sobre 1946-1964 esbarram no desafio em que todo exame ex post se depara: explicar os eventos sem condicioná-los ao desfecho conhecido. Do ponto de vista do comportamento dos partidos no Legislativo, inexistem indícios para decretarmos que a instauração liberal rumaria ao interregno autoritário subsequente. Divisões intrapartidárias não comprometiam automaticamente a ordem, a menos que os instrumentos de coordenação falhassem.

(Recebido para publicação em abril de 2014) (Aprovado para publicação em maio de 2015) 
Facciosismo, Rachas Intrapartidários e Capacidade Decisória na Democracia...

\section{NOTAS}

1. O art. 39 da Lei Agamenon, como ficou conhecido o decreto no 7.586 , de 28 de maio de 1945, estabeleceu que só poderiam concorrer às eleições candidatos registrados por partidos ou alianças de partidos.

2. Esta avaliação segue reproduzida em trabalhos recentes. Prova disso é o estudo de Mona Lyne (2008), que endossa o argumento fundado nas mazelas do clientelismo sobre a performance legislativa no Brasil do pós-guerra.

3. Algumas pesquisas ainda associam a duração da primeira experiência democrática brasileira ao poder gozado pelos pessedistas no plano local, garantindo a adesão dos "coronéis" ao governo bem como o enquadramento da massa eleitoral, diretamente controlada pelos chefes locais (Benevides, 1979; Camargo, 1973).

4. Segundo Figueiredo e Limongi, o plenário da experiência anterior parece menos polarizado do que o do regime democrático atual. Nas palavras dos autores, "A maioria do PSD tendeu a dominar o plenário e o fez fazendo alianças circunstanciais à direita e à esquerda. No governo Dutra e no governo Café Filho, o partido tendeu mais à direita. No restante do período, tendeu mais à esquerda, juntando-se, em geral, ao PTB e, também, ao PSP" (Figueiredo e Limongi, 1998:18).

5. Os critérios apresentados por Figueiredo (2008) na definição das coalizões existentes na época e suas respectivas composições constam reproduzidos no Apêndice A e baseiam a análise oferecida neste artigo.

6. Na prática, isto significaria que a disciplina partidária seria tão menor quanto maior se mostrasse o information effect, e, quanto maior ele fosse, mais fortes seriam os incentivos para formar coalizões sobredimensionadas a fim de diminuí-lo.

7. Os autores chegam a esta conclusão a partir da adoção de um proxy para patronagem - no caso, um indicador de verbas orçamentárias alocadas aos partidos pelos presidentes que dirigiram o país entre 1946 e 1964. Entendem, ainda, que a ausência do imperativo da reeleição naquele período comprometia o custeio da patronagem (Amorim Neto e Santos, 2001).

8. Computando todos os integrantes das várias correntes intrapartidárias emergidas entre 1946 e 1964 mencionados pela literatura, foi possível identificar somente 88 deputados. Destes, constam 7 Raposas (ou pessedistas tradicionais) e 11 reformistas da legenda (a chamada Ala Moça, envolvida com a revitalização dos métodos do PSD). Também se distinguiram 10 membros da Banda de Música (alcunha aplicada aos udenistas que faziam barulho diário no plenário em discursos inflamados contra o governo); 5 Chapas-Brancas (que, ao contrário dos colegas de bancada, procuravam se compor com o Executivo) e 26 participantes da Bossa Nova (também contrários à conduta dos seus correligionários da Banda de Música, se reúnem em 1961 para apoiar as propostas nacionalistas de Jânio Quadros). Os demais dissidentes conhecidos dividem-se entre as várias alas do trabalhismo - a saber: os ademaristas (2); os teóricos (3); os fisiológicos (5); os radicais (2) e o grupo compacto (3) - e outras orientações ideológicas menores, que somam 14 elementos.

9. O debate sobre o conteúdo da policy e a variação nos resultados deliberativos não é novo. Remonta a Mayhew (1991). Para um balanço desta discussão, ver Ricci (2002).

10. Somente depois da referida atualização normativa, a indicação da preferência de cada sigla representada na Câmara entraria para a rotina regimental da Casa. Antes 


\section{Jaqueline Porto Zulini}

disso, os líderes partidários raramente orientavam a posição do partido que representavam, tendendo a subir à tribuna, para encaminhamento de votação, na qualidade de parlamentares com visão crítica da matéria a ser decidida. O ponto será discutido melhor mais adiante, quando trato das especificidades do processo deliberativo em 1946-1964.

11. A declaração da validade era encargo do presidente da sessão, que deveria legitimar (ou não) a decisão do plenário em função da existência/ausência de quorum. Este procedimento também será digno de maior detalhamento em seção posterior.

12. Vale frisar que os cálculos referem-se exclusivamente às iniciativas do Executivo ou de sua base parlamentar que foram alvo de votação nominal na Câmara dos Deputados. Muitos projetos podem ser aprovados ou rejeitados em decisões simbólicas. Os números, portanto, não reportam o sucesso do Executivo entendido como a taxa de aprovação dos projetos apresentados.

13. Das 89 iniciativas do Executivo que restam com o emprego desse critério, o governo sai vitorioso em $78(87,6 \%)$. Quanto às iniciativas de sua base parlamentar na Câmara, as vitórias se consumam em $268(85,4 \%)$ dos 403 casos.

14. São também nas mesmas coalizões que a ajuda da oposição se mostra capital na aprovação de 89 (33,3\%) das 268 iniciativas da base parlamentar governista na Câmara: Vargas I (8) e II (52), além de registros em JK I (20) e II (7).

15. Os próprios Verge e Gómez (2012) assumem condensar em poucas palavras as visões de Belloni e Beller (1978:447), Boucek (2009:14) e Zariski (1960:33) sobre o a noção de facciosismo.

16. Tradicional medida de coesão partidária, o índice de Rice é obtido através do resultado, em módulo, da subtração da porcentagem de votos contrários contados no seio de uma legenda $X$ a partir da porcentagem de votos favoráveis registrados pela mesma sigla numa dada votação nominal $Y$. Ou seja, $\mathrm{R} y, \mathrm{x}=\mid \%$ de votos $\operatorname{sim}-\%$ de votos não|. Desconsiderando, portanto, os casos de abstenção declarada, as ausências e a obstrução parlamentar, o escore abrange apenas os deputados que votaram pela aprovação ou rejeição da matéria em deliberação, invariavelmente somando 1 (um). Disso se depreende que, na prática, um partido só atingirá os 100\% no índice de Rice caso todos os seus membros votem da mesma forma durante uma decisão nominal. Por extensão, o indicador cairá para 0 (zero) se a agremiação rachar ao meio, isto é, quando o número de votos sim equivaler à soma dos votos não (Rice, 1925).

17. Cf. Constituição Federal de 1946, art. 42.

18. Eis a determinação do art. $140, \S 3^{\circ}$, do referido texto.

19. É importante frisar que a norma procedural então em voga associa o termo "verificação por bancadas" exclusivamente a fileiras de assentos no plenário da Câmara dos Deputados, e não a bancadas parlamentares enquanto grupos políticos com interesses em comum, por exemplo. A palavra tem apelo físico, não político. Como, na prática, tal checagem equivalia à avaliação da existência de quorum legal para deliberação, passo a chamar o procedimento daqui por diante de "verificação de quorum.

20. Cf. Resolução noำ 10, de 1947, art. 129, § 4으.

21. Incorporo, aqui, reflexões acerca das diferenças de significado político entre votações simbólicas e nominais tecidas por Carvalho (1973), que não abordou as verificações de quorum em suas explanações. 
22. Pelo regimento de 1934, todo pedido de verificação seria deferido (art. 238, §1ํㅡ). A necessidade de apoio ao parlamentar requerente da verificação seria introduzida apenas com a Resolução nํㅗㄹㄹ, de 1955, que reclamava a adesão de pelo menos mais 20 deputados para conceder a petição (art. 140, § $3^{\circ}$ ).

23. Não por acaso, inclusive, Lúcia Hippólito (1985) pode ter se esquecido de citar a passagem de Flores da Cunha (UDN / RS) no mais alto cargo da Câmara dos Deputados ao frisar que todos os presidentes da Mesa Diretora entre 1946 até 1964 teriam sido pessedistas: Fernando Melo Viana (presidente da Casa à época da Assembleia Nacional Constituinte), Samuel Duarte (1947-1948), Cirilo Júnior (1949-1950), Nereu Ramos (1951-1954), Carlos Luz (1954-1955), Ulysses Guimarães (1956-1958) e Ranieri Mazzili (1958-1964) - representantes, portanto, do partido que deteve a maioria das cadeiras em todas as legislaturas da democracia populista (Hippólito, 1985:68, nota 22). Afinal, Cunha deixaria a UDN pouco antes de assumir a direção dos trabalhos legislativos no plenário, em 1955. Gaúcho e influente em seu estado, o deputado não representava exatamente uma descontinuidade na hegemonia do PSD naquela cátedra pela sua condição de independência frente à cúpula udenista. Constituía, antes, uma ótima escolha aos olhos do maior partido do pré-1964, enfraquecido que era o pessedismo no Rio Grande do Sul.

24. Segundo os autores, nas ocasiões mais importantes e críticas, vitórias estreitas seriam muito mais frequentes do que perdas estreitas. Além disso, em questões-chave, as lideranças amargariam derrotas por margens maiores frente à folga verificada em vitórias sobre matérias de igual teor.

25. Carvalho (1973) já havia destacado esta fase. Analisando apenas as votações nominais no mandato JK, a autora notou a maior recorrência desta forma de deliberação nos anos pós-eleitorais (1956 e 1959). A seu ver, isto evidenciaria "o conflito entre ou dentro dos partidos para a 'renumeração' das bases estaduais e locais dos deputados pelo apoio recebido durante o período eleitoral" (Carvalho, 1973:197, ênfases minhas). De fato, mais de um terço das votações com exposição pública dos parlamentares (checagem de quorum e chamada nominal) recai sobre emendas orçamentárias na administração JK - 40,3\%, para ser exata (220) -, uma conhecida forma dos congressistas pleitearem a alocação de recursos em favor de seus redutos eleitorais. Tal procedimento ainda é o foco de $76,9 \%$ (70), 41,6\% (32) e 25,2\% (60) das contestações de resultado nos governos Café Filho, Goulart e Vargas, respectivamente. Nas demais presidências, porém, não atingem $10 \%$ dos casos.

26. Vale lembrar que ambos foram alçados à chefia do Executivo pela porta dos fundos, no esteio de uma crise política iniciada com a morte de Vargas e intensificada após falhos conchavos encabeçados pela própria UDN para impedir a posse de Juscelino e Goulart, vencedores da corrida presidencial de 1954.

27. Fecham a porcentagem $1,2 \%$ de pedidos de verificação de autoria desconhecida (isto é: as vezes em que o nome do parlamentar requerente não aparece nos diários da Câmara) e os $0,2 \%$ casos avulsos - categoria exclusiva para o governo de Mazzili, meramente transitório e sem a formação de coalizão parlamentar de apoio ao presidente, de modo a inviabilizar a classificação da autoria dos pedidos de verificação de votação concedidos à época.

28. Quando se trata de matérias apresentadas pelo Poder Executivo, a oposição aciona o pedido de verificação em $74,1 \%$ dos casos, contra $23,8 \%$ das solicitações governistas, além dos casos sem informação (2,2\%). Já em proposições formalizadas pelo Poder 


\section{Jaqueline Porto Zulini}

Legislativo, a oposição deflagra requerimentos de verificação em $66,3 \%$ das observações, contra $32,4 \%$ dos pedidos de membros da coalizão e 1,4\% das ocorrências sem informação de autoria.

29. Para enveredar na discussão sobre práticas obstrucionistas, o trabalho de Eric Schickler (2001) é um ótimo começo.

30. As outras origens das votações nominais ocorridas na época foram os requerimentos pleiteando esse método deliberativo $(7,4 \%)$ e os casos em que o procedimento nominal é compulsório (3,3\%).

31. $18,8 \%$ das verificações de quorum não foram realizadas em função da opção do presidente da Câmara em realizar diretamente a votação nominal. Os pedidos de checagem do número legal foram retirados pelos respectivos requerentes em $0,2 \%$ das ocasiões. Não há informação sobre os resultados das verificações em $0,1 \%$ dos casos.

32. Não foi possível precisar a influência do presidente da Câmara em $0,2 \%$ dos casos. 
Facciosismo, Rachas Intrapartidários e Capacidade Decisória na Democracia...

\section{REFERÊNCIAS BIBLIOGRÁFICAS}

AMORIM NETO, Octavio; SANTOS, Fabiano. (2001), "A Conexão Presidencial: Facções Pró e Antigoverno e Disciplina Partidária no Brasil". DADOS - Revista de Ciências Sociais, vol. 44, no 2, pp. 291-321.

BANDEIRA, Luiz A. Moniz. (1983), O Governo João Goulart: As Lutas Sociais no Brasil (1961-1964). Rio de Janeiro (6a ed.). Civilização Brasileira.

BELLONI, Frank P.; BELLER, Dennis C. (1978), Faction Politics: Political Parties and Factionalism in Comparative Perspectives. Santa Barbara, CA, ABC-Clio Inc.

BENEVIDES, Maria Victoria de Mesquita. (1979), O Governo Kubitschek: Desenvolvimento Econômico e Estabilidade Política (1956-1961). Rio de Janeiro, Paz e Terra.

. (1981a), A UDN e o Udenismo: Ambiguidades do Liberalismo Brasileiro (1945-1965). São Paulo, Paz e Terra.

. (1981b), O Governo Jânio Quadros. São Paulo, Brasiliense.

BOUCEK, Françoise. (2009), “Rethinking Factionalism Typologies, Intra-Party Dynamics and Three Faces of Factionalism". Party Politics, vol. 15, o 4, pp. 1-31.

CAMARGO, Aspásia A. de. (1973), Brésil Nord-Est: Mouvements Paysans et Crise Populiste. Tese (Doutorado em Sociologia), Université Paris II, Paris.

(1981), “A Questão Agrária: Crise de Poder e Reformas de Base (1930-1964)”, in B. Fausto (org.), História Geral da Civilização Brasileira - Tomo III - O Brasil Republicano. São Paulo, Difel.

CARDOSO, Fernando Henrique. (1978), "Partidos e Deputados em São Paulo, o Voto e a Representação Política", in B. Lamounier; F. H. Cardoso (orgs.), Os Partidos e as Eleições no Brasil. (2a ed.). Rio de Janeiro, Paz e Terra.

CARVALHO, Maria Izabel Valladão. (1973), “Mecanismo Conflitual de Decisão na Câmara dos Deputados: O Significado Político da Votação Nominal no Período 1956-1960. Dados Preliminares". DADOS - Revista de Ciências Sociais, no 11, pp. 194-205.

(1977), A Colaboração do Legislativo para o Desempenho do Executivo durante o Governo JK. Dissertação (Mestrado em Ciência Política). Instituto Universitário de Pesquisas do Rio de Janeiro (Iuperj), Rio de Janeiro.

D’ARAÚJO, Maria Celina Soares. (1992), O Segundo Governo Vargas (1951-1954). São Paulo, Ática.

FIGUEIREDO, Argelina Cheibub. (2008), “Government Coalitions in Brazilian Democracy". Brazilian Political Science Review, vol. 1, no 2, pp. 182-216.

; LIMONGI, Fernando. (1998), Relação Executivo-Legislativo no Presidencialismo Multipartidário: Os Regimes de 46 e 88. Trabalho apresentado no XXII Encontro Anual da Anpocs. Caxambu, 27-31 de outubro.

. (1999), Executivo e Legislativo na Nova Ordem Constitucional. Rio de Janeiro, FGV Editora.

DADOS - Revista de Ciências Sociais, Rio de Janeiro, vol. 58, nº 4, 2015 


\section{Jaqueline Porto Zulini}

. (2007), “Instituições Políticas e Governabilidade: Desempenho do Governo e Apoio Legislativo na Democracia Brasileira", in C. Ranulfo (org.), A Democracia Brasileira: Balanço e Perspectivas para o Século 21. Belo Horizonte, UFMG Editora.

HIPPÓLITO, Lúcia. (1985), De Raposas e de Reformistas: O PSD e a Experiência Democrática Brasileira (1945-64). Rio de Janeiro, Paz e Terra.

KING, David C.; ZECKHAUSER, Richard J. (2003), “Congressional Vote Options”. Legislative Studies Quarterly, vol. 28, no 3, pp. 387-411.

LAFER, Celso. (1970), The Planning Process and the Political System in Brazil: AStudy of Kubitschek's Target Plan, 1956-1961. Tese (Doutorado em Ciência Política). Cornell University, New York.

. (2002), JKe o Programa de Metas (1956-1961): Processo de Planejamento e Sistema Político no Brasil. Rio de Janeiro, FGV Editora.

LEAL, Victor Nunes. (1975) [1949], Coronelismo, Enxada e Voto: O Município e o Regime Representativo no Brasil. São Paulo, Alfa-Omega.

LYNE, Mona. (2008), The Voter's Dilemma and Democratic Accountability: Explaining the Democracy-Development Paradox. Pennsylvania, PA, The Pennsylvania State University Press.

MAYHEW, David R. (1991), Divided we Govern. Party Control, Lawmaking, and Investigations, 1946-2002. New Haven/London, Yale University Press.

OLIVEIRA, Lúcia Lippi de. (1973), “Notas sobre o Estudo do Partido Social Democrático". DADOS - Revista de Ciências Sociais, no 10, pp. 146-153.

PETERSEN, Phyllis J. (1962), Brazilian Political Parties: Formarion, Organization, and Leadership, 1945-1959. Tese (Doutorado em Ciência Política). University of Michigan, Michigan.

RICCI, Paolo. (2002), “A Medida das Leis: Do Uso de Noções Genéricas à Mensuração do Imponderável". Revista Brasileira de Informação Bibliográfica em Ciências Sociais (BIB), no 54, pp. 101-123.

RICE, Stuart. (1925), "The Behavior of Legislative Groups: A Method of Measurement". Political Science Quarterly, vol. 40, no 1, pp. 60-72.

RIKER, William H. (1962), The Theory of Political Coalitions. New Haven, Yale University Press.

SAIEGH, Sebastian M. (2011), Ruling by Statute: How Uncertainty and Vote-Buying Shape Lawmaking. New York, Cambridge University Press.

SAMPAIO, Regina. (1982), Adhemar de Barros e o PSP. São Paulo, Global.

SANTOS, Fabiano. (1997), "Patronagem e Poder de Agenda na Política Brasileira". DADOS - Revista de Ciências Sociais, vol. 40, no 3, pp. 465-492.

. (2002), "Partidos e Comissões no Presidencialismo de Coalizão". DADOS - Revista de Ciências Sociais, vol. 45, no 2, pp. 237-264.

. (2003), O Poder Legislativo no Presidencialismo de Coalizão. Belo Horizonte, UFMG Editora. 
Facciosismo, Rachas Intrapartidários e Capacidade Decisória na Democracia...

SANTOS, Wanderley Guilherme dos. (1973), "Coalizões Parlamentares e Instabilidade Governamental: A Experiência Brasileira - 1961/1964". Revista de Administração de Empresas, vol. 13, no 4, pp. 61-71.

. (2003), O Cálculo do Conflito: Estabilidade e Crise na Política Brasileira. Belo Horizonte, UFMG Editora.

SARTORI, Giovanni. (1983), Partidos e Sistemas Partidários. Rio de Janeiro, Zahar.

SCHICKLER, Eric. (2001), Disjointed Pluralism: Institutional Innovation and the Development of the U.S. Congress. Princeton, Princeton University Press.

SCHWARTZMAN, Simon. (1971), "Veinte Años de Democracia Representativa en Brasil, 1945-1964". Revista Latinoamericana de Ciencia Política, vol. II, no 1, pp. 24-46.

SKIDMORE, Thomas. (1975), Brasil: De Getúlio a Castelo. Rio de Janeiro, Paz e Terra.

SOUZA, Maria do Carmo Campello de. (1976), Estado e Partidos Políticos no Brasil. São Paulo, Alfa-Omega.

VERGE, Tània; GÓMEZ, Raúl. (2012), “Factionalism in Multi-level Contexts: When Party Organization becomes a Device". Party Politics, vol. 18, no 5, pp. 667-685.

ZARISKI, Raphael. (1960), “Party Factions and Comparative Politics: Some Preliminary Observations". Midwest Journal of Political Science, vol. 4, pp. 27-51. 


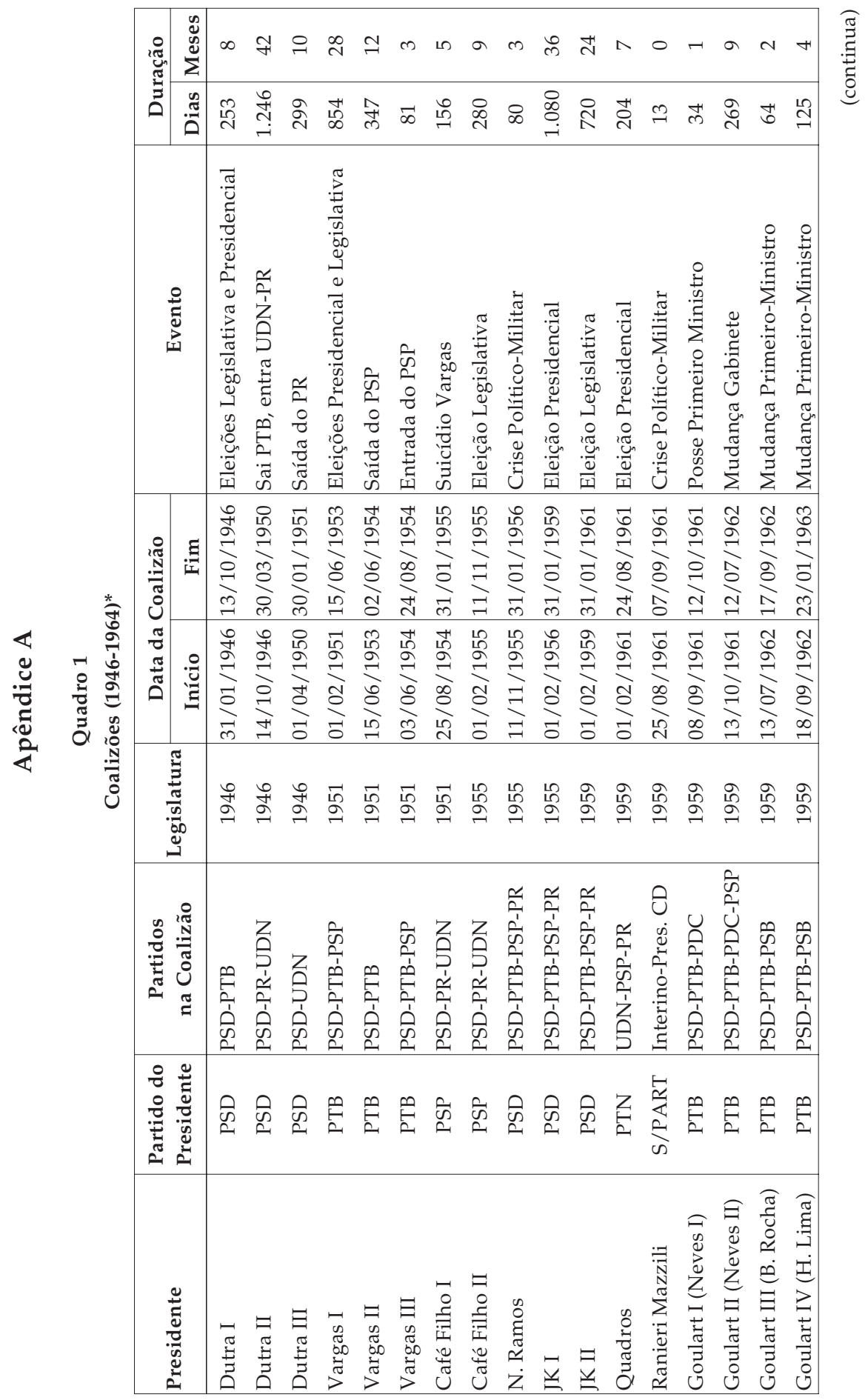

1050 DADOS - Revista de Ciências Sociais, Rio de Janeiro, vol. 58, nn 4, 2015 
Facciosismo, Rachas Intrapartidários e Capacidade Decisória na Democracia...

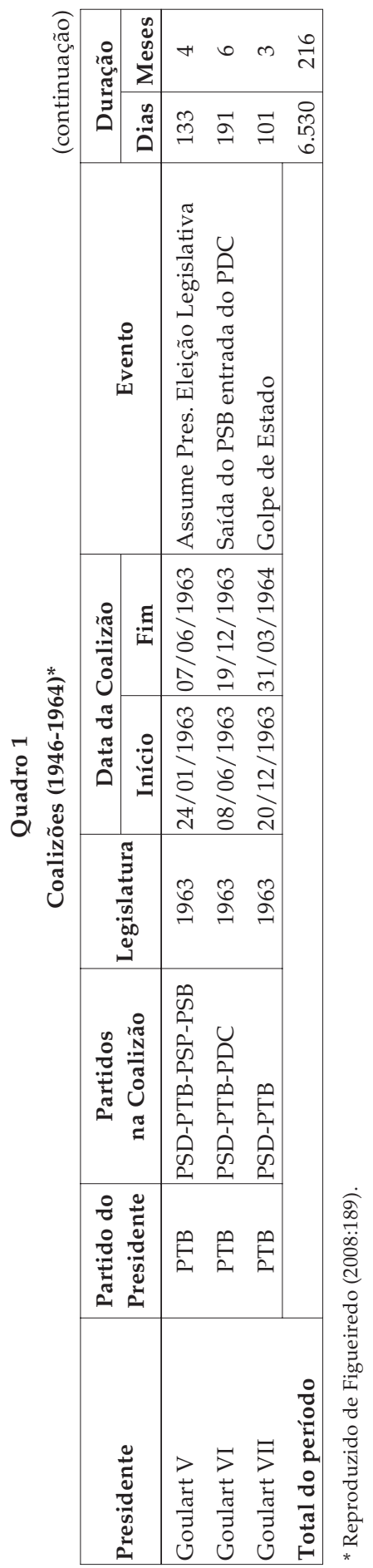




\section{Apêndice B}

\section{Nota Metodológica}

É corrente a suspeição de que as ações dos legisladores em plenário se modificassem segundo os interesses políticos do governo envolvidos na apreciação de temas que estivessem sob a orla da sua agenda de trabalho. Para alguns autores, a tese das coalizões ad hoc poderia estar sobredimensionada justamente em função de uma desavisada orientação empírica, considerando-se que muitas votações nominais abarcam questões irrelevantes. Figueiredo e Limongi já alertaram para o fato de que, eventualmente, uma subamostra de matérias de interesse do executivo pudesse revelar maior coesão e um padrão de coalizões mais estável durante a democracia de 1946 (1998:20). Para os propósitos deste artigo, isso indicaria a possibilidade de a Mesa seguir uma conduta diversa na apreciação de políticas realmente importantes ao Poder Executivo.

Reunir as matérias mais caras às administrações da época, todavia, é tarefa custosa. A maioria dos trabalhos que tratam dessas questões, ora conjunturais, ora perenes, constituem estudos de caso, esmagadoramente voltados aos governos Vargas e Kubitschek, por motivos vários. Nesta perspectiva, a saída para se compilar a lista de temas que gozavam de primazia entre 1946 e 1964 foi adaptar o critério adotado por Mayhew (1991), fundado no reconhecimento dos tópicos como prioritários pela bibliografia especializada. Cada política objeto de votação nominal foi assim classificada se admitida como tal por pelo menos um autor que se dedicou ao exame da democracia de 1946.

No Quadro 2 está o resultado deste arranjo, que se limitou a sintonizar os registros históricos com as observações empíricas de verificações de votação. Como se vê, políticas sociais são secundárias, predominando questões inerentes ao bom exercício das finanças públicas, sem o controle das quais nenhuma administração se faria promissora. 
Facciosismo, Rachas Intrapartidários e Capacidade Decisória na Democracia...

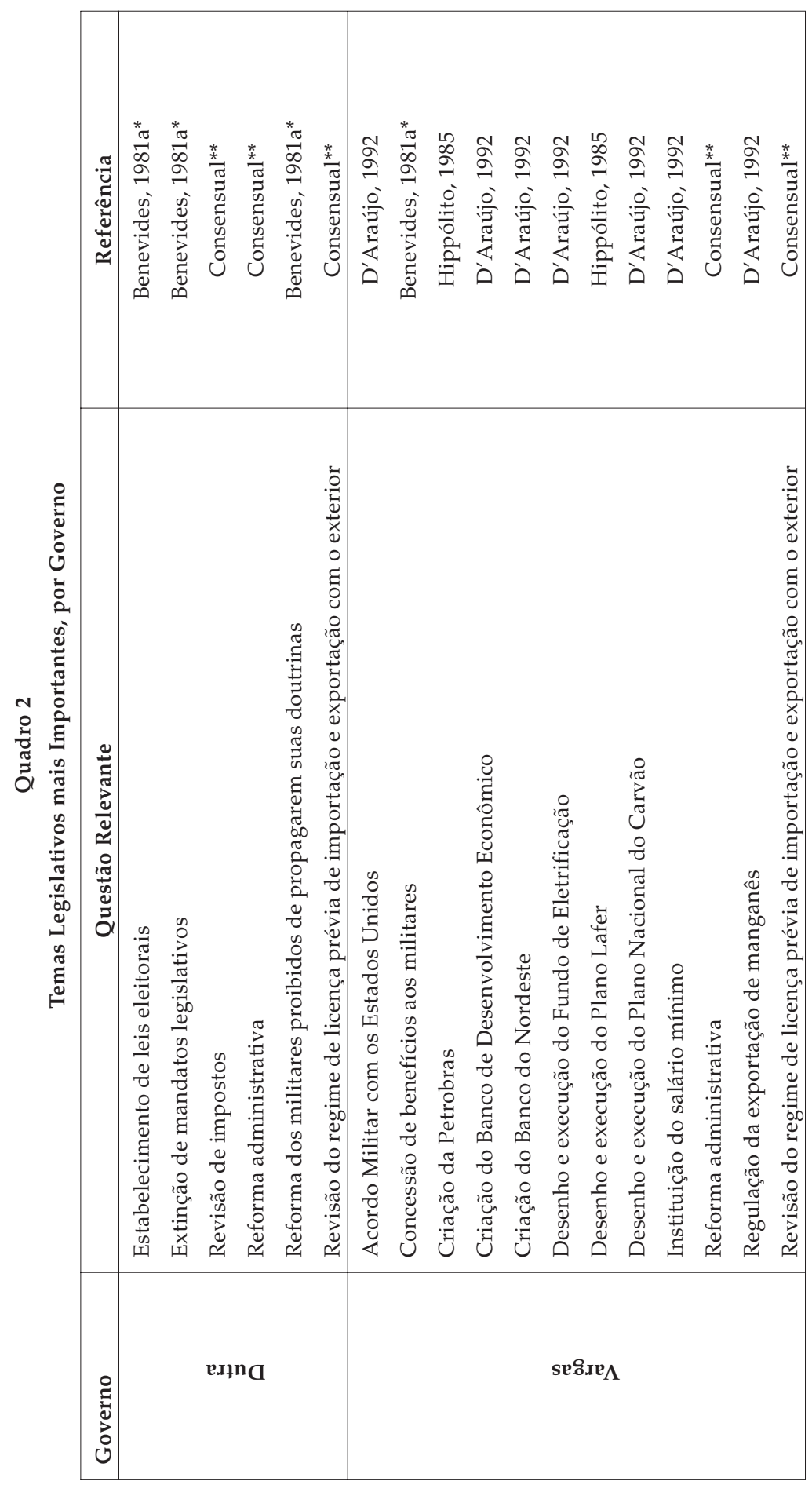




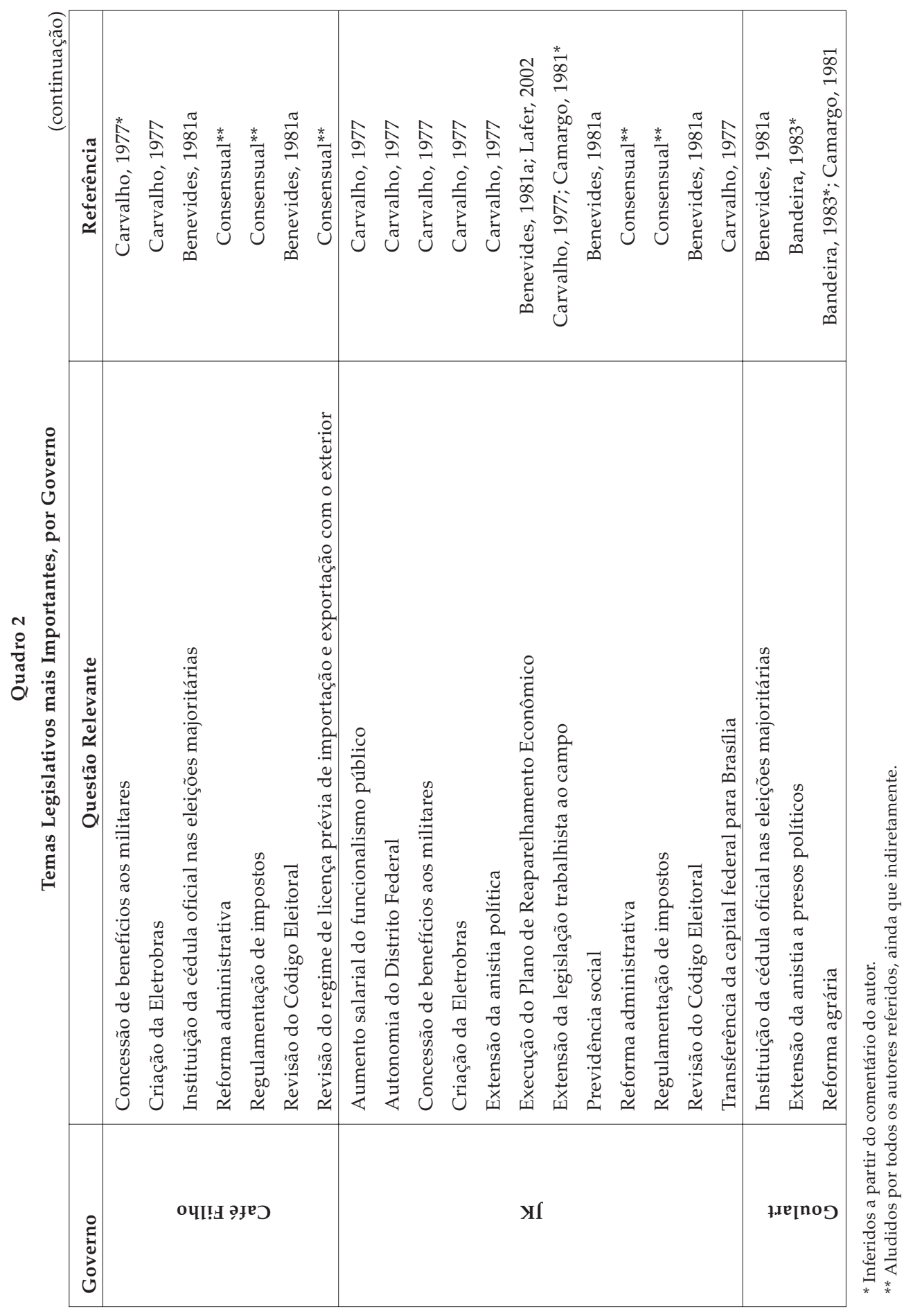

1054 DADOS - Revista de Ciências Sociais, Rio de Janeiro, vol. 58, no 4, 2015 
Facciosismo, Rachas Intrapartidários e Capacidade Decisória na Democracia...

\section{RESUMO}

Facciosismo, Rachas Intrapartidários e Capacidade Decisória na

Democracia Brasileira de 1946

A literatura aponta o facciosismo como norma do sistema partidário vigente à democracia de 1946, supostamente governada por coalizões parlamentares concebidas ad hoc. O propósito deste artigo é questionar o impacto dos rachas político-ideológicos no Legislativo via exame das votações ocorridas na Câmara Federal desde a instauração liberal até o final do regime, que mostram ser incomum a base governista necessitar de auxílio externo para aprovar a própria agenda. Veremos que somente nas gestões Vargas e Kubitschek as contribuições da oposição se fizeram capitais na passagem dos programas presidenciais, tendo as metas varguistas dependido mais deste subsídio. A hipótese desenvolvida é que o êxito governamental, em geral, dependia do uso estratégico da verificação de quorum, um procedimento regimental capaz de publicizar a divisão de forças no plenário de maneira a viabilizar a coordenação da própria coalizão no poder.

Palavras-chave: democracia brasileira; 1946; facções; maioria legislativa; coalizões partidárias

\section{ABSTRACT \\ Factionalism, Intraparty Divides and Decision Capacity during the 1946 Brazilian Democratic Period}

Literature points to factionalism as the norm of the party system during the democratic period that started in 1946 in Brazil, in which ad hoc parliamentary coalitions assumedly governed. The purpose of this article is to question the impact of political-ideological divides in the Legislative by means of the examination of votes in the Federal Chamber from the liberal instauration until the end of the regime. These votes show how uncommon it was for the government to require outside help to approve its agenda. We will show that only during the Vargas and Kubitschek administrations did contributions from the opposition become capital in the approval of presidential programs, being that Vargas relied more on this aid. The hypothesis developed is that governmental success in general depended on the strategic use of the quorum verification, a procedural rule capable of exposing publicly the division of forces on the floor so as to enable the coordination of the coalition in power.

Keywords: Brazilian democracy; 1946; factions; legislative forces; party coalitions 


\section{RÉSUMÉ}

Esprit de Chapelle, Scissions Partisanes et Capacité Décisionnelle dans la Démocratie Brésilienne de 1946

La littérature nous montre la tendance à la scission comme une norme du système partisan en vigueur à partir de la démocratie de 1946, qu'étaient censées gouverner des coalitions parlementaires créées ad hoc. Le but de cet article est d'analyser l'impact des scissions politico-idéologiques sur le pouvoir législatif à travers l'examen des votes tenus dans la Chambre fédérale depuis l'instauration du régime libéral jusqu'à sa chute, et de révéler ainsi qu'il n'était pas courant pour la coalition gouvernementale d'avoir besoin de soutiens extérieurs pour faire approuver son programme. Nous verrons que c'est seulement lors des mandats de Kubitschek et plus encore de Vargas que les contributions de l'opposition sont devenues capitales pour l'approbation des programmes présidentiels. Notre hypothèse est que le succès gouvernemental dépendait généralement de l'usage stratégique de la vérification du quorum, une procédure réglementaire capable d'exposer la division des forces en séance plénière de manière à viabiliser la coordination de la coalition au pouvoir.

Mots-clés: démocratie brésilienne; 1946; factions; majorité parlementaire; coalitions partisanes

\section{RESUMEN}

\section{Espírito Faccioso, Grietas Intrapartidistas y Capacidad Decisoria en la Democracia Brasileña de 1946}

La literatura subraya el elemento faccioso como norma del sistema de partidos vigente en la democracia brasileña de 1946, supuestamente gobernada por coaliciones parlamentarias ad hoc. El objetivo de este artículo es cuestionar el impacto de las cisiones político-ideológicas en el Legislativo a través del análisis de las votaciones ocurridas en la Cámara Federal desde la instauración liberal hasta el final del régimen, que muestran que es poco habitual que la base gubernista necesite apoyo externo para aprobar su propia agenda. Veremos que sólo en las gestiones Vargas y Kubitschek las contribuciones de la oposición se hicieron importantes en los programas presidenciales, llegando a ser centrales para las metas varguistas. La hipótesis desarrollada es que el éxito gubernamental, en general, dependía del uso estratégico de la verificación de quórum, un procedimiento regimental capaz de tornar pública la división de fuerzas en el plenario de tal forma que permitía viabilizar la coordinación de la propia coalición en el poder.

Palabras clave: democracia brasileña; 1946; facciones; mayoría parlamentaria; coaliciones partidarias 